\title{
Aircraft observations of cold pools under marine stratocumulus
}

\author{
C. R. Terai and R. Wood \\ Department of Atmospheric Sciences, University of Washington, Seattle, WA 98195, USA \\ Correspondence to: C. R. Terai (terai@ atmos.washington.edu) \\ Received: 11 April 2013 - Published in Atmos. Chem. Phys. Discuss.: 24 April 2013 \\ Revised: 19 August 2013 - Accepted: 30 August 2013 - Published: 8 October 2013
}

\begin{abstract}
Although typically associated with precipitating cumuli, cold pools also form under shallower stratocumulus. This study presents cold-pool observations as sampled by the NSF/NCAR C-130, which made cloud and boundarylayer measurements over the southeast Pacific stratocumulus region at an altitude of approximately $150 \mathrm{~m}$ during the VOCALS Regional Experiment. Ninety edges of cold pools are found in the C-130 measurements by identifying step-like changes in the potential temperature. Examination of their mesoscale environment shows that the observed cold pools tend to form under heavier precipitation, thicker clouds, and in cleaner environments. Cold pools are also found to form under clouds with high LWP values over the night of or before sampling. When they form, cold pools often form in clusters or on top of each other, rather than as separate, individual entities. Their sizes range from $2 \mathrm{~km}$ to $16 \mathrm{~km}$ (middle 50th percentile), where the largest of cold pools are associated with the greatest drops in temperature. Composites of various observed thermodynamic and chemical variables along the cold-pool edges indicate increased humidity, equivalent potential temperature, coarse-mode aerosol, and dimethyl sulfide concentration inside cold pools. The enhancements inside cold pools are consistent with increased static stability that traps fluxes from the ocean surface in the lowest levels of the boundary layer. By using pressure perturbations, the average cold pool is estimated to be approximately $300 \mathrm{~m}$ deep. The temperature depression in cold pools also leads to density-driven flows that drive convergence of horizontal winds and measurable, mechanically driven vertical wind velocity at the edges of cold pools.
\end{abstract}

\section{Introduction}

The formation of pools of cold, relatively high-density air at the surface, or cold pools, represents one key way in which precipitation from convective clouds organizes cloud fields. Because the evaporation and melting of precipitation is the primary driver of cold pools (Srivastava, 1987), the strongest cold pools are typically found under heavily precipitating cumulonimbus clouds, the characteristics of which have been extensively studied (e.g., Charba, 1974; Goff, 1976; Wakimoto, 1982; Engerer et al., 2008). Cold pools are found close to the surface and spread outward from the source of cold air (Droegemeier and Wilhelmson, 1987). They play a role in the organization of precipitation cells by triggering new convection at their edges via mechanical lifting at the edges (Rotunno et al., 1988) or by priming surface air with high concentrations of water vapor (Tompkins, 2001).

Cold-pool formation, however, is not limited to heavily precipitating deep cumulonimbus but is also observed under shallow clouds with cloud tops below $2 \mathrm{~km}$ (Jensen et al., 2000; Van Zanten and Stevens, 2005; Comstock et al., 2005, 2007; Wood et al., 2011a; Zuidema et al., 2012a). Modeling studies have highlighted the importance of cold pools in determining the mesoscale organization of cloud fields across a range of cloud types, scales, and environments, for example, stratocumulus in Savic-Jovcic and Stevens (2008); deep maritime convection in Khairoutdinov et al. (2011); and trade cumulus in Seifert and Heus (2013). Under marine stratocumulus in particular, cold pools are characterized by reduced temperatures, increased water vapor mixing ratios, and increased equivalent potential temperatures $\left(\theta_{\mathrm{e}}\right)$, and have a characteristic depth of a few hundred meters (Jensen et al., 2000; Comstock et al., 2007; Feingold et al., 2010). The elevated $\theta_{\mathrm{e}}$ inside cold pools was initially surprising (Van Zanten and Stevens, 2005) given that precipitation evaporation 
alone cannot increase $\theta_{\mathrm{e}}$, because evaporation conserves the moist static energy. In an earlier modeling study, Mechem and Kogan (2003) noted the possibility that stratification induced by the cold pool can trap surface fluxes near the surface and increase $\theta_{\mathrm{e}}$, a hypothesis later confirmed by SavicJovcic and Stevens (2008). Elevated $\theta_{\mathrm{e}}$ is not always associated with cold pools forming under precipitating clouds. In their observational study of cold pools under precipitating trade cumuli, Zuidema et al. (2012a) found reduced $\theta_{\mathrm{e}}$ in cold pools and showed how this is achieved by precipitationdriven downdrafts that pull down drier air from aloft. This is also found in cold pools under deep cumulonimbus (Engerer et al., 2008).

Cold pools under stratocumulus are thought to be necessary for the formation and maintenance of pockets of open cells (POCs) in marine stratocumulus. POCs are regions of open cell convection surrounded by a larger region of closed cell convection commonly found in the subtropical marine stratocumulus regions (Stevens et al., 2005; Comstock et al., 2007; Wood et al., 2011a). All POC observations have found evidence of cold pools (Van Zanten and Stevens, 2005; Comstock et al., 2007; Wood et al., 2011a), and large eddy simulations of POCs have shown how cold pools concentrate the areas of ascent to drive the open cell convection in POCs (Wang and Feingold, 2009; Feingold et al., 2010; Wang et al., 2010; Berner et al., 2011). Whereas precipitation is a necessary ingredient for cold-pool formation and appears necessary for POC formation, it remains to be seen whether coldpool formation in marine stratocumulus is a sufficient condition for the formation of open cells. It is also unclear under what range of marine boundary layer (MBL) and cloud conditions cold pools can form.

The rate at which precipitation falls from stratocumulus clouds is largely controlled by the liquid water path (LWP), or alternatively cloud thickness, and the cloud droplet number concentration (Geoffroy et al., 2008; Wood, 2012). The latter is closely related to the accumulation mode aerosol concentration in marine environments (Martin et al., 1994), and this is also the case over the southeastern Pacific (SEP, Terai et al., 2012). In this region, the cloud droplet number concentration decreases and the cloud thickness increases westward away from the South American coast (Bretherton et al., 2010). In response, mean cloud base precipitation rates increase from $<0.2 \mathrm{~mm} \mathrm{~d}^{-1}$ close to the coast to values in excess of $1 \mathrm{~mm} \mathrm{~d}^{-1}$ further offshore around $85^{\circ} \mathrm{W}$ (Bretherton et al., 2010; Wood, 2012). This would suggest that cold pools will be preferentially found further away from the coast.

In this study we incorporate measurements from thirteen flights of the NSF/NCAR C-130 research aircraft to study cold pools that form under the clouds over the SEP. The flights took place as part of the VOCALS Regional Experiment (Wood et al., 2011b) and sampled a wide range of stratocumulus clouds including both thin, overcast stratocumulus close to the Chilean coast to thick and more strongly precipitating clouds within POCs. Section 2 introduces the data set and the criteria by which we identify cold pools. Section 3 examines the mesoscale features that accompany cold pools compared with cases without cold pools. Section 4 then examines cold-pool characteristics by comparing the air inside the cold pool to that of the environment, examining closely the kilometer scale changes at the cold-pool edges. Section 5 provides further discussion on the mean characteristics of the cold pools and what observations tell us about their role in affecting MBL structure.

\section{Data and methods}

\subsection{Data}

The VOCALS (VAMOS Ocean-Cloud-Atmosphere-Land Study) Regional Experiment (REx) was an international field experiment conducted in October to November 2008 to better understand processes and interactions that maintain the climate system of the SEP (Wood et al., 2011b). The analysis in this study is based on aircraft observations from thirteen research flights (RF02-RF14) that the NSF/NCAR C130 flew during REx. Because our focus is on cold pools that form in the lower MBL, data from the subcloud flight legs - flown at approximately $150 \mathrm{~m}$ altitude - are the primary source of data. Because previously observed depths of cold pools under stratocumuli range from 100 to $500 \mathrm{~m}$ (Jensen et al., 2000; Comstock et al., 2007; Feingold et al., 2010), we expect the subcloud flight legs to sample most cold pools present along flight legs. The in situ thermodynamic, chemical, and dynamic measurements, as well as radar and lidar estimates of the overlying cloud and precipitation properties, are retrieved at $1 \mathrm{~Hz}$, which approximates to a spatial resolution of $100 \mathrm{~m}$.

We use 87 subcloud flight legs, most of which are $60 \mathrm{~km}$ in length, except for legs flown in POCs, which were 150$250 \mathrm{~km}$ in length. Their locations span from 70 to $85^{\circ} \mathrm{W}$ and from 17 to $28^{\circ} \mathrm{S}$ (see Fig. 6). This data set is appropriate for studying cold pools in a large range of potential stratocumulus conditions. Along $20^{\circ} \mathrm{S}$, sea surface temperatures from 75 to $85^{\circ} \mathrm{W}$ increase from approximately 17.5 to $18.5^{\circ} \mathrm{C}$ (Bretherton et al., 2010), while lower tropospheric stability over the same span decreases from approximately 26 to $23 \mathrm{~K}$ (Toniazzo et al., 2011). The instruments used to measure the thermodynamic and dynamic state variables (temperature, pressure, water vapor mixing ratio, and horizontal and vertical winds) are given in Wood et al. (2011b). The humidity measurements are taken from the fast response UV humidity sensor because of its fast response time that is necessary to capture any changes in humidity across a cold-pool edge. Because the UV humidity sensor was inoperable during RF06, humidity values from the reference thermoelectric dew-point sensor are used for that flight.

Since previous modeling studies have suggested that cold pools trap surface heat fluxes, we also examine 
measurements of chemical and aerosol tracers with sources at the surface. To study the aerosol properties within the cold pools, we use measurements from the Passive Cavity Aerosol Spectrometer Probe (PCASP) and the Cloud Droplet Probe (CDP). The PCASP measures aerosols in the dry size (diameter) range of $0.1-3 \mu \mathrm{m}$, whereas the CDP, which is normally used to measure cloud droplets in the size range of 1-24 $\mu \mathrm{m}$, can also measure large or hydrated aerosols in the same size range. Heaters in the PCASP are used to heat the airstream to below $30 \%$ relative humidity $(\mathrm{RH})$, whereas the CDP measures the aerosols at ambient RH (typically $>70 \%$ for subcloud legs). To ensure that splashing/shattering drizzle drops do not affect the aerosol measurements, a drizzle filter is applied to remove aerosol data if any of the following conditions are met: liquid water content $>0.04 \mathrm{~g} \mathrm{~m}^{-3}$ (as measured by the Gerber PV-100 Probe); drizzle drop concentration $>1 \mathrm{~L}^{-1}$ (as measured by the 2DC Probe); a 10 s-lagged, $11 \mathrm{~s}$-mean drizzle water content $>10^{-4} \mathrm{~g} \mathrm{~m}^{-3}$ (as measured by the 2DC Probe).

Properties of clouds above the cold pools are obtained using retrievals from the Wyoming Cloud Lidar (WCL), the Wyoming Cloud Radar (WCR), and the G-band Vapor Radiometer (GVR). Cloud base height is estimated from the WCL by determining the height of maximum gradient in lidar backscatter (Wang et al., 2009). When heavy drizzle rates preclude accurate cloud base height estimation from the WCL, the altitude of maximum reflectivity from the WCR is used as the cloud base height, because the two are found to track each other with a bias of $22 \mathrm{~m}$ and root mean square error of $280 \mathrm{~m}$ from the VOCALS data. Cloud top height is retrieved from the WCR by determining the maximum height where the power return and the variance of the Doppler velocity exceed threshold values. Note that cloud top heights were not retrievable for clouds with low radar reflectivity. Hence, only $80 \%$ of cloud top heights were obtained for cloud columns in which the maximum column reflectivity exceeded $-20 \mathrm{dBZ}$. The LWP of the cloud is retrieved from the GVR, following Zuidema et al. (2012b). Drizzle occurrence at the flight level is obtained from the $2 \mathrm{DC}$ probe. We use a drizzle water content threshold of $0.02 \mathrm{~g} \mathrm{~kg}^{-1}$ to indicate drizzle occurrence, which corresponds to a precipitation rate of roughly $1 \mathrm{mmd}^{-1}$.

Satellite data are used to obtain information about the mesoscale cloud fields in which cold pools form. Visible radiance images and infrared brightness temperatures (centered on a wavelength of $11 \mu \mathrm{m}$ ) from the Geostationary Operational Environmental Satellite imager (GOES-10), obtained roughly every fifteen minutes, are used to study the cloud morphology around cold pools. A four-times daily data set ( 6:00/18:00 and 2:00/14:00 local time) of LWP retrievals is obtained at a $0.25^{\circ}$ resolution from a number of polar orbiting passive microwave satellites (Advanced Microwave Sounding Radiometer-EOS, AMSR-E; WindSat; Special Sensor Microwave/Imager on the Defense Meteorological Satellite Program platforms) that was constructed over the SEP using data from Remote Sensing Systems, Santa Rosa (http://www.ssmi.com) and the methods described by Wentz (1997), Wentz and Meissner (2000), and Hilburn and Wentz (2008).

To track changes in mesoscale cloud morphology before and after the time of cold-pool sampling, 2-D isobaric backward and forward trajectories at $950 \mathrm{hPa}$ were calculated from the European Centre for Medium Range Weather Forecasting (ECMWF) operational analyses as described by George et al. (2013).

\subsection{Identifying cold pools in the data}

Cold pools are most easily identified in the subcloud flight legs as an abrupt drop in potential temperature $(\theta)$. An example of a temperature time series from a subcloud leg under overcast stratocumulus from research flight RF04 on $23 \mathrm{Oc}-$ tober 2008 (Fig. 1) shows that in most cases where there is a drop in $\theta$, there is a subsequent increase in water vapor mixing ratio $\left(q_{\mathrm{v}}\right)$. This is indicative of drizzle evaporation (Paluch and Lenschow, 1991; Jensen et al., 2000; Comstock et al., 2005). The drops in $\theta$ also coincide at times with thick clouds, which are more likely to produce heavy drizzle (Geoffroy et al., 2008; Terai et al., 2012). Although there are drops in $\theta$ in Fig. 1 that do not correspond to increases in cloud thickness, possibly due to the lag between the precipitation event and aircraft sampling, we discuss in Sects. 3.3 and 4.3 how cold-pool occurrence correlates with cloud thickness. In this study changes in $\theta$ alone are used to identify the edges of cold pools, which we henceforth refer to as cold-pool edges.

To capture the step-like change in $\theta$ across a cold-pool edge while excluding spurious turbulent spikes in $\theta$, we experimented with different $\theta$ threshold criteria to define a cold-pool edge. To help visualize how we identify the coldpool edges, an idealized $\theta$ time series is shown in Fig. 2. We designate a particular data point at time $t$ in the time series for a cold-pool edge if the following conditions are all satisfied

$$
\begin{aligned}
& \Delta \theta_{\mathrm{a}}=\theta\left(t-t_{2}\right)-\theta(t) \geq \Delta \theta_{2}, \\
& \Delta \theta_{\mathrm{b}}=\theta\left(t-t_{1}\right)-\theta(t) \geq \Delta \theta_{1}, \\
& \Delta \theta_{\mathrm{c}}=\theta(t)-\theta\left(t+t_{1}\right) \geq \Delta \theta_{1}, \text { and } \\
& \Delta \theta_{\mathrm{d}}=\theta(t)-\theta\left(t+t_{2}\right) \geq \Delta \theta_{2},
\end{aligned}
$$

where $\Delta \theta_{1}=0.06 \mathrm{~K}$ and $\Delta \theta_{2}=0.12 \mathrm{~K}$. Whereas the previous criteria ensure that random temperature spikes in the data are not identified as cold-pool edges, we allow for two sets of spatial intervals, where either $t_{1}=2 \mathrm{~s}$ and $t_{2}=4 \mathrm{~s}$ or $t_{1}=3 \mathrm{~s}$ and $t_{2}=6 \mathrm{~s}$, to prevent the turbulent spikes from hindering the identification of cold-pool edges. Roughly speaking, an edge is identified if four $\theta$ measurements over $200 \mathrm{~m}$ or $300 \mathrm{~m}$ intervals each decrease by more than $0.06 \mathrm{~K}$. If consecutive data points in a time series satisfy the criteria, then the median among those data points is chosen as the 

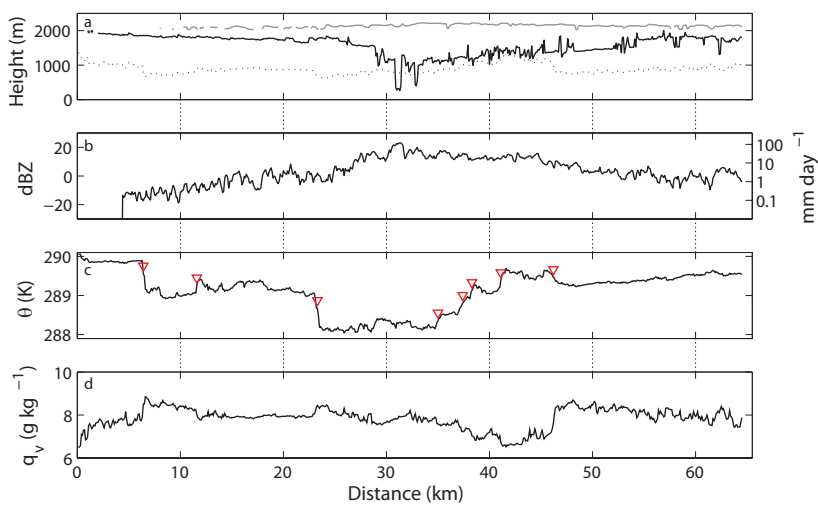

Fig. 1. Time series of aircraft data from a subcloud flight leg $\left(\sim 150 \mathrm{~m}\right.$ ) flown during RF04 (23 October $2008 \sim 10: 00$ UTC $20^{\circ} \mathrm{S}$ $83^{\circ} \mathrm{W}$ ): (a) cloud top height (gray), cloud base height (solid black), and lifting condensation level at aircraft height (Bolton, 1980, dotted); (b) cloud base radar reflectivity, as measured by the WCR, and corresponding precipitation rate using a $Z-R$ relationship from Comstock et al. (2004); (c) in situ potential temperature $(\theta)$, where the red triangles indicate the location of cold-pool edges, as identified by the criteria described in the text; (d) in situ water vapor mixing ratio $\left(q_{\mathrm{v}}\right)$. The distance along the $x$ axis is approximated from the time series assuming the aircraft flies at a mean ground speed of $100 \mathrm{~ms}^{-1}$.

cold-pool edge. The same process is run in reverse to identify cold-pool edges that involve $\theta$ increasing in time. The values of $\Delta \theta_{1}$ and $\Delta \theta_{2}$ are chosen such that the step-wise changes identified with the criteria largely match those identified by eye. The number of cold-pool edges and magnitude of the changes observed across edges is sensitive to the choice of $\Delta \theta_{1}$ and $\Delta \theta_{2}$ but the key conclusions of this study are unaffected by the choice.

Cold-pool edges identified in this way are indicated by red triangles in the $\theta$ time series of Fig. 1c. Despite the subjective choice of thresholds, the criteria can be applied to the data from all 87 subcloud flight legs of the C-130, and the coldpool edges can then be used to composite the data. The main disadvantage to using the drop in $\theta$ is that it misses cold pools whose abrupt $\theta$ drops over the sub-kilometer scale have recovered either due to mixing or surface fluxes. The method is also unable to identify small scale cold pools where the temperature jumps occur over spatial scales $<400 \mathrm{~m}$. Despite these potential shortcomings, the $\theta$ criteria provide a basis to compare cold pools and their surroundings across 90 coldpool edges distributed over 21 of the 87 flight legs.

\section{Atmospheric conditions when cold pools are observed}

\subsection{Size}

The size $L$ of cold pools on a given flight leg is determined by examining the two sets of cold-pool edges that involve

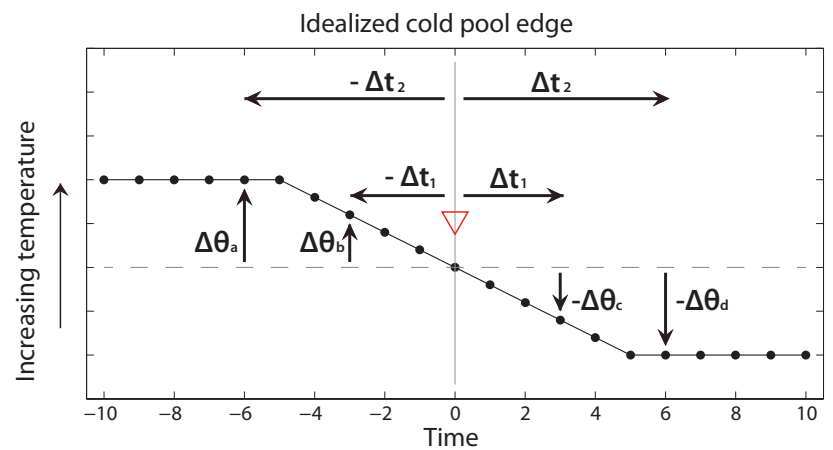

Fig. 2. Schematic showing how cold pools are identified in the potential temperature $(\theta)$ time series. Along the $x$ axis, time $t$ increases to the right, while along the $y$ axis, $\theta$ increases upward. In this case, the data point at time $t=0$ is identified a cold pool if $\Delta \theta_{\mathrm{a}}, \Delta \theta_{\mathrm{b}}$, $\Delta \theta_{\mathrm{c}}$, and $\Delta \theta_{\mathrm{d}}$ satisfy the criteria.

$\theta$-increasing and $\theta$-decreasing with time along the leg. For each $\theta$-decreasing edge, we examine the $\theta$ time series at subsequent times up to the time (if one exists) when the temperature recovers to the value it had at the edge itself. We denote this time the recovery time. If a second $\theta$-increasing edge is found within $10 \mathrm{~s}(\sim 1 \mathrm{~km})$ of the recovery time for the first edge, then we denote the pair as being two edges of the same cold pool. The time between these two cold-pool edges is reported as its size. However, there are instances where a $\theta$-increasing edge is not detected. For such cases, the coldpool size is reported as the time between the $\theta$ decreasing edge and the recovery time for that edge. If $\theta$ does not recover before the end of a flight leg, then a cold-pool size is not reported. Indeed, sizes for 15 of the total 80 cold pools identified were excluded for this reason. We expect therefore that our cold-pool size distribution (Fig. 4) has a low bias for larger cold pools. Since the aircraft flew straight legs at a rate of $\sim 100 \mathrm{~m} \mathrm{~s}^{-1}$ (average airspeed of $105 \mathrm{~m} \mathrm{~s}^{-1}$ with a standard deviation of $2 \mathrm{~m} \mathrm{~s}^{-1}$ ), the time interval is then converted into a distance using the $100 \mathrm{~m} \mathrm{~s}^{-1}$ approximation. The size of the cold pools identified in this way for the flight leg in Fig. 1 is shown in Fig. 3. Note that cold pools determined using our approach can be overlapping, such that smaller cold pools can be found embedded within larger cold pools. We run the algorithm in the forward direction and then in the reverse direction to identify all the unique cold pools.

The cumulative size distribution $f(L)$ of all the observed cold pools is shown in Fig. 4. We correct the measured distribution $f_{\mathrm{m}}(L)$ on a leg-by-leg basis to account for the undersampling of larger cold pools by limited leg length $L_{\text {leg }}$ using the method used in Wood and Field (2011):

$f(L)=f_{\mathrm{m}}(L) \frac{L_{\mathrm{leg}}}{L_{\mathrm{leg}}-L}$.

For cold pools smaller than $20 \mathrm{~km}$ ( $90 \%$ of the observed cold pools), this weight is typically between 1.0 and 1.5. 

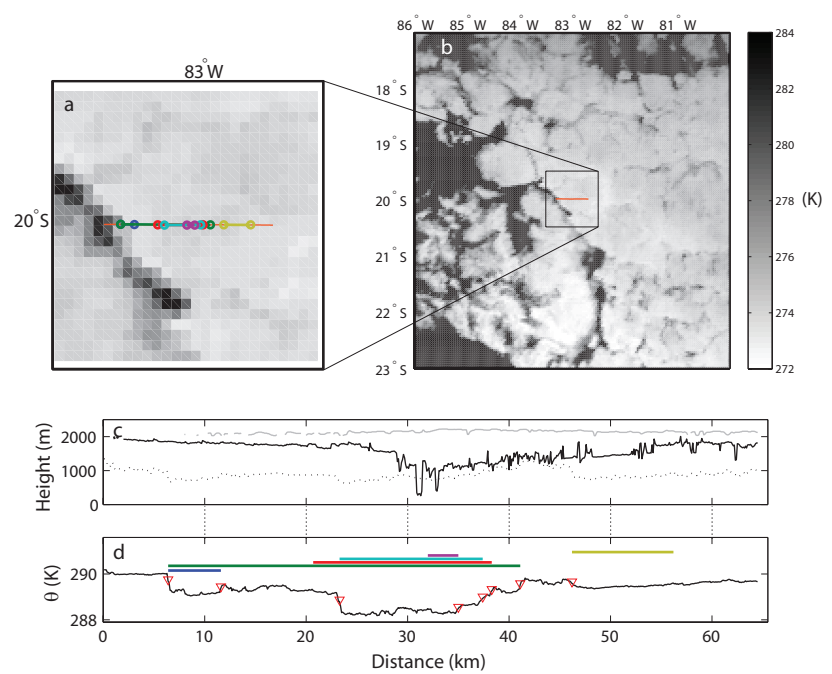

Fig. 3. The top panels show the GOES-10 satellite imagery from $11 \mu \mathrm{m}$ channel in a $1^{\circ}$ (a) and $6^{\circ}$ square box (b) centered on the flight leg (orange) taken during the flight leg (23 October 2008 at 10:28 UTC). (c) Corresponds to Fig. 1a, where cloud top height (gray), cloud base height (solid black), and LCL (dotted) are shown. The $\theta$ time series in (d) shows the location and size of cold pools detected by the algorithm described in the text. Each colored segment over the $\theta$ time series represents an individual cold pool.

The median size of the corrected size distribution is $\sim 6 \mathrm{~km}$, and the middle 50th percentile of the distribution lies between $2 \mathrm{~km}$ and $16 \mathrm{~km}$. The large cold pools $(>50 \mathrm{~km})$ are mostly cold pools associated with POCs, whose contribution may appear anomalous. That said, Comstock et al. (2005) found similarly anti-correlated mesoscale variations on scales of $50-100 \mathrm{~km}$ in surface layer temperature and moisture over the SEP. The size distribution suggests that for computer simulations to accurately represent the interaction of cold pools under marine stratocumulus, their domain size needs to be significantly greater than $10 \mathrm{~km}$. Figure 4 also shows that $f(L)$ largely follows a log-normal distribution $(\mu=2.45$ and $\sigma=1.25)$. It should also be noted that since the aircraft did not necessarily intersect the centers of the cold pools, if we assume that the cold pools are circular and that flight transects are uniformly distributed along the diameter of cold pools, we expect the lengths to be underestimated by approximately $25 \%$ (a factor of $4 / \pi$ ). This $4 / \pi$ factor is not reflected in Fig. 4.

We find a strong negative correlation between the coldpool size and the mean temperature difference between inside and outside the cold pool (Spearman rank correlation of -0.76 , Fig. 5). To obtain the temperature outside of the cold pools, we take the mean temperature from the $2.5 \mathrm{~km}$ segments on either side of the cold pool. This strong correlation suggests that more cooling leads to larger cold pools. When taken with the finding above (Fig. 3) that large cold pools are associated with clusters of cold pools, however, we speculate

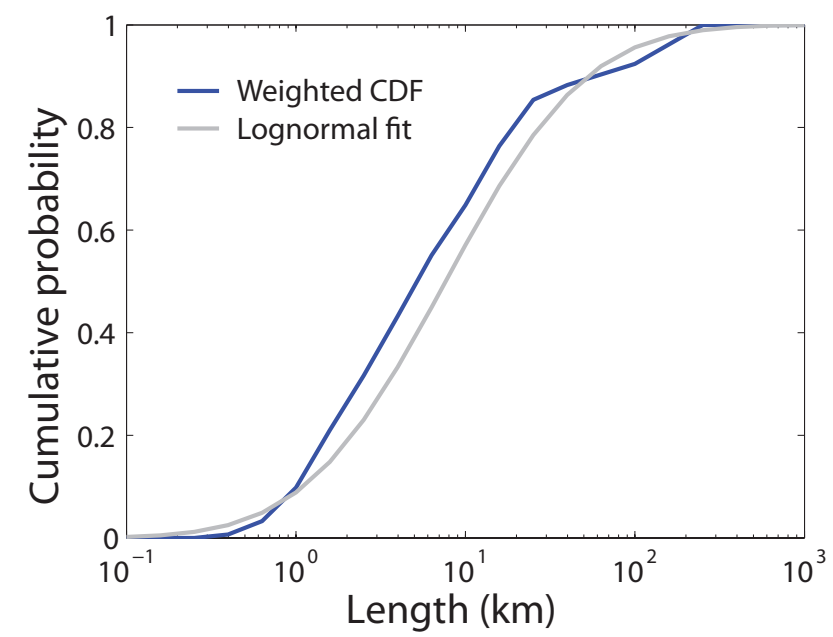

Fig. 4. Cumulative distribution of the observed cold-pool size (blue), where each cold pool is weighted using Eq. (5). Note that the $x$ axis is log-scale and size bin widths are equal in log-space. The log-normal fit (mean of the natural $\log$ arithm $\mu=2.45$ and standard deviation of the natural logarithm $\sigma=1.25$ ) based on the weighted data is plotted in gray.

that large cold pools are not formed from larger precipitation cells, but from the clustering of multiple cells, where new cold pools form within older cold pools, effectively lowering the temperature inside the older cold pools. Indeed, the mean precipitation rate over the cold pool and its size do not correlate well. The clustering of cold pools is so common that of the 80 identified cold pools, 42 of them were found embedded within a larger cold pool. Although comparisons of the edges do not reveal systematic thermodynamic differences in the air mass of the embedded cold pools, the precipitation rate at the edge of embedded cold pools tends to be higher.

\subsection{Location}

Because mean precipitation rate increases westward from the South American coast (Leon et al., 2008; Bretherton et al., 2010; Wood et al., 2011b) and because strong mesoscale variability in temperature is associated with precipitation rates $>1 \mathrm{mmh}^{-1}$ (Comstock et al., 2005), we expect cold pools to preferentially form further away from the coast. Our observations confirm this (Fig. 6), with no cold pools observed within $500 \mathrm{~km}$ of the Chilean coast (i.e., east of $75^{\circ} \mathrm{W}$ ). One caveat is that the coastal pollution flight legs that extended from $20^{\circ} \mathrm{S}$ to $28^{\circ} \mathrm{S}$ were conducted during the day when drizzle is less frequently observed (Leon et al., 2008) and less heavy (Burleyson et al., 2013). However, many of the legs along $20^{\circ} \mathrm{S}$, east of $75^{\circ} \mathrm{W}$, were at night when precipitation is favored. The numbers of cold-pool edges in each leg (Fig. 6) indicates that cold pools are usually clustered together, such that if one cold pool is observed on a flight leg, there is a high likelihood that another cold pool is observed on the same leg. Thus the example shown in Fig. 3 


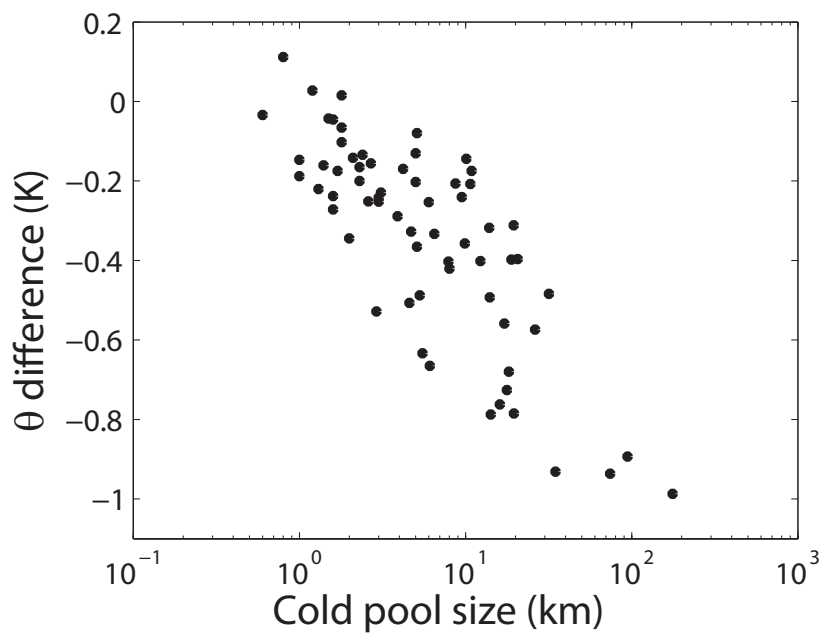

Fig. 5. The cold-pool size plotted against the $\theta$ difference between mean $\theta$ inside the cold pool and mean $\theta 2.5 \mathrm{~km}$ outside the cold pool.

is actually quite typical; cold pools are not typically found by themselves, and interactions between cold pools must be studied when trying to understand their effect on the marine boundary layer (MBL).

\subsection{Boundary-layer characteristics}

Cold pools form under precipitating clouds and so we expect cold pools to form preferentially in MBLs with strong precipitation. In Fig. 7, we have plotted the flight leg mean cloud base precipitation rate against the leg mean cloud thickness. As in other studies (Bretherton et al., 2010; Wood et al., 2011a; Terai et al., 2012), the mean precipitation rate is estimated from the cloud base WCR reflectivity using the $Z$ $R$ relationship from Comstock et al. (2004). Open circles differentiate legs that traversed POCs from those that did not. Thicker clouds tend to produce higher precipitation rates and those legs with cold pools clearly are those with thicker clouds and heavier precipitation. That said, Fig. 7 also shows that cold pools were not observed on a number of flight legs where the mean precipitation rate exceeded $1 \mathrm{mmd}^{-1}$. The reader should be aware of the limits to interpreting this figure. Precipitation rates and cloud thickness are spatially variable and cold pools can still be observed after the precipitation event that formed them has dissipated, so one should not expect the association between precipitation, cloud thickness, and cold-pool occurrence to be a perfect one given the nature of the aircraft sampling.

Looking at larger scale boundary-layer features, we would expect cold pools to form preferentially when MBLs are deeper and when CCN concentrations are low, enhancing precipitation (Terai et al., 2012). This is especially pertinent to the currently unresolved issue about the conditions necessary and sufficient for POC formation. Observational studies

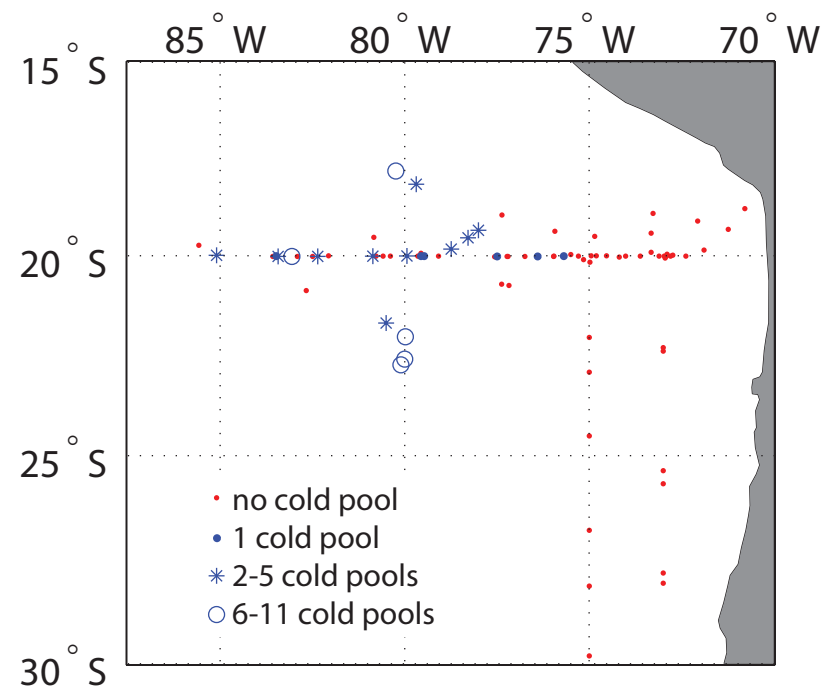

Fig. 6. Geographic location of subcloud flight legs flown by the C130 during VOCALS-REx. Red dots indicate legs in which no cold pools were observed. Blue dots indicate legs in which 1 cold pool was observed, while the stars indicate where $2-5$ and open circles indicate where $6-11$ cold pools were observed.

of POCs have all found cold pools in POCs (Van Zanten and Stevens, 2005; Comstock et al., 2007; Wood et al., 2011a) and results from modeling studies point to the importance of cold pools in maintaining and forming POCs (Savic-Jovcic and Stevens, 2008; Wang and Feingold, 2009; Berner et al., 2011). Although we will not address whether cold-pool formation eventually leads to POC formation in this study, we can address whether clean environments and deeper MBLs are associated with cold-pool formation. Figure 8 shows that cold pools are indeed generally found in deeper MBLs $(>1300 \mathrm{~m}$ ) with low accumulation mode aerosol concentrations. Low aerosol concentrations for legs with cold pools may reflect the effect of precipitation scavenging in lowering aerosol concentrations. However, cold pools can exist for aerosol concentrations as high as $200 \mathrm{~cm}^{-3}$. The mean cloud thickness in those particular cases are roughly $400 \mathrm{~m}$, but as Fig. 7 indicates, none of the factors, including the precipitation rate, taken separately, are perfect predictors of cold-pool formation.

\subsection{Satellite derived cloud field}

Although satellite images, in conjunction with the aircraft cold-pool observations, provide a way of showing case studies of where cold pools are observed in relation to cloud features (Fig. 3), these satellite images can also be used to examine mesoscale morphology of clouds associated with cold pools. Previous studies have found that heavier drizzle is observed more frequently under open cellular regions (clouds broken on the mesoscale), compared to closedcellular regions (associated with overcast, homogeneous 


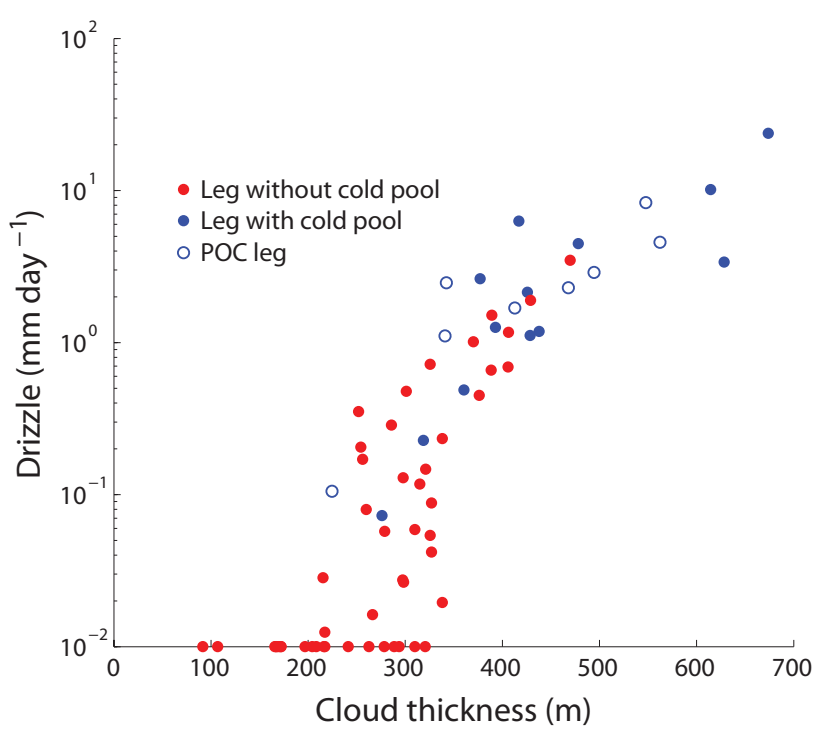

Fig. 7. Leg-mean cloud base precipitation rates, estimated from WCR radar reflectivity and $Z-R$ relationship from Comstock et al. (2004), are plotted against the leg-mean cloud thicknesses for legs with (blue) and without (red) cold pools. Open circle indicate legs located in pockets of open cells, all of which had cold pools.

clouds) (Stevens et al., 2005; Sharon et al., 2006; Comstock et al., 2007). Because surface precipitation is a good indicator of cold pools (Sect. 4.1; Comstock et al., 2005), we expect to preferentially find cold pools under more broken clouds.

We compare cloud heterogeneity around flight legs with and without cold pools. To quantify the degree of heterogeneity, we calculate the standard deviation of $4 \mathrm{~km}$ resolution GOES-10 IR Channel $4(\lambda \sim 11 \mu \mathrm{m})$ brightness temperature $\left(T_{\mathrm{B}}\right)$ over a $1^{\circ} \times 1^{\circ}$ box centered on the flight leg (see Fig. 3a for an example). The standard deviation of $T_{\mathrm{B}}$ of the box in Fig. $3 \mathrm{a}$ is $1.73 \mathrm{~K}$. The $T_{\mathrm{B}}$ of adjacent pixels in an overcast cloud deck does not vary by much $(<3 \mathrm{~K})$, but the variability is much higher for broken clouds (up to $8 \mathrm{~K}$ ). The $8 \mathrm{~K}$ difference is close to the temperature difference between the cloud top and the sea surface below. Most of the $T_{\mathrm{B}}$ variability comes from the degree of brokenness in the cloud field, rather than the variation in cloud top temperatures, since those with high variance in the $T_{\mathrm{B}}$ exhibit a bimodal distribution in $T_{\mathrm{B}}$ (see also Coakley and Bretherton, 1982). A histogram of the standard deviation of $T_{\mathrm{B}}$ for the two populations of flight legs (with cold pools and without cold pools) shows that the population of legs with cold pools has a different $T_{\mathrm{B}}$ distribution (Fig. 9), where legs with cold pools are more preferentially located in areas with broken clouds. On the other hand, some cold pools are also found in regions with overcast cloud fields. We conclude that while drizzle is a necessary condition for the formation of cold pools, a broken cloud field, usually associated with precipitating cumulus clouds, is not a necessary condition for the formation of cold pools. Furthermore, if we follow the

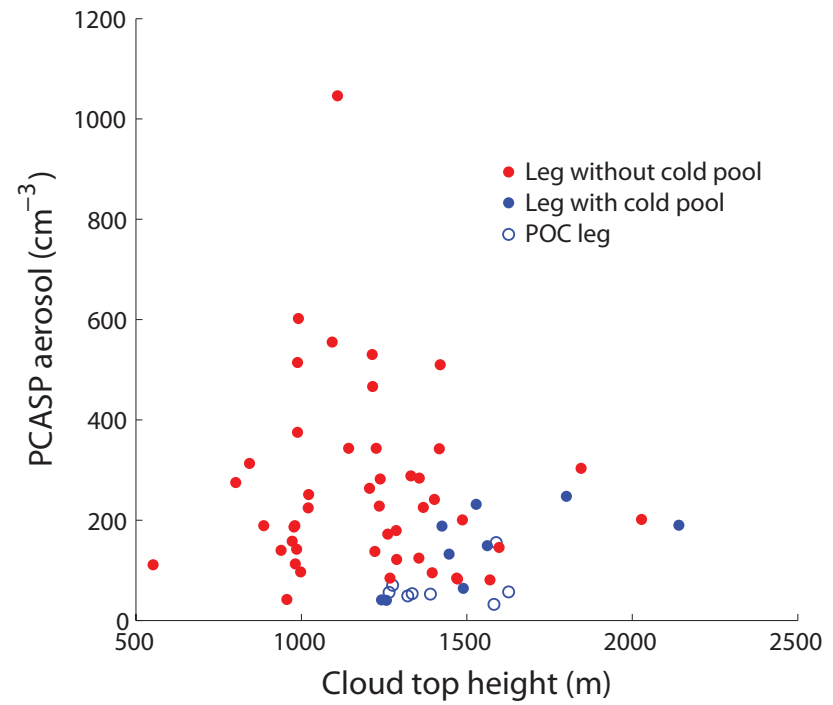

Fig. 8. Leg-mean PCASP aerosol concentrations are plotted against the leg-mean cloud top heights obtained from the WCR for legs with (blue) and without (red) cold pools. Open circle indicate legs located in pockets of open cells, all of which had cold pools.

temporal evolution of cloud field $T_{\mathrm{B}}$ using forward trajectories calculated from ECMWF wind fields (George et al., 2013), we find no indication that cold-pool formation preferentially leads to clouds breaking up (not shown), suggesting that cold-pool formation does not necessarily lead to cloud breakup.

We can pursue the relationship between drizzle and cold pools further by looking at the satellite passive microwave data set. Whereas the aircraft only provides a snapshot of the cloud field that lies over the observed cold pools, the satellite retrievals allow us to look at the temporal evolution of the clouds leading to sampling the cold pools. Because drizzle rates increase with increasing LWP under marine stratocumuli (e.g., Comstock et al., 2004), we compare the satellite derived LWP for legs with and without cold pools. Since continuous passive microwave retrievals cannot be obtained, as they can from the geostationary GOES-10, we determine the location at the time of the previous satellite overpass of the air mass sampled by the flight leg using backward trajectories calculated from ECMWF. The backward trajectories also allow us to follow the $24 \mathrm{~h}$ evolution of LWP leading up to the sampling of the flight leg. Figure 10 plots satellite-derived LWP averaged over $2^{\circ} \times 2^{\circ}$ boxes surrounding the tracked location of the leg air mass against the time in UTC. We plot LWP against UTC instead of against hours before/after the aircraft leg time to avoid mixing diurnal variability with other variability. Cloud LWP over legs with cold pools is in most cases higher than the cloud LWP of clouds over legs without cold pools. The nighttime/early morning maximum LWP $(\sim 08: 00$ and $\sim$ 12:00 UTC retrievals $)$ before aircraft sampling has some predictive power of cold-pool 


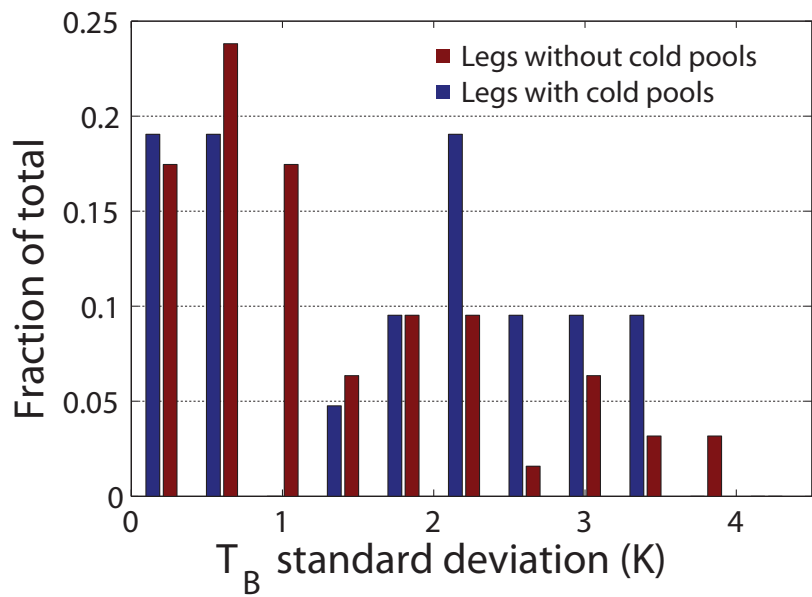

Fig. 9. Histogram indicating the fraction of legs found under different cloud fields. Each bar represents the fraction of legs with or without cold pools in which the standard deviation of the brightness temperature $\left(T_{\mathrm{B}}\right)$ of the $1^{\circ}$ box centered on the leg.

formation, but the LWP of the previous afternoon $(\sim 20: 00$ and $\sim$ 00:00 UTC retrievals) does not differentiate legs with and without cold pools.

\section{Composites across cold-pool edge}

\subsection{Thermodynamics}

We now switch from looking at the large-scale differences to small scale differences seen across cold pools. Looking at small scale changes across cold-pool edges can inform us how cold pools differ from the environment and how they affect boundary-layer processes. Overlying cloud properties, as well as thermodynamic, dynamic, and chemical properties of the air mass are composited as a function of distance from the cold-pool edge for the 90 identified edges to examine the characteristic differences between the cold pool and the ambient subcloud layer. One important caveat is that 42 of the 90 cold-pool edges were found embedded within larger cold pools. Since we are primarily interested in how the air inside the cold pool differs from the air outside, rather than the mean state, we composite the deviations of the state variables from the value at the edge, unless noted otherwise. For all composite plots we show the mean values and the $95 \%$ confidence interval of the mean calculated using Student $t$ statistics, assuming that each cold-pool edge is independent. The composites are oriented with the cold pool to the right. A mean drop of $0.4 \mathrm{~K}$ in potential temperature $\theta$ (Fig. 11a and Table 1) is observed across the cold-pool edge, which is substantially larger than the minimum threshold of $0.24 \mathrm{~K}$ set by the $\theta$ criteria (Sect. 2.2). The mean drop is sensitive to the choice of threshold, but this does not change the general conclusions in this study. As $\theta$ drops, water vapor mixing
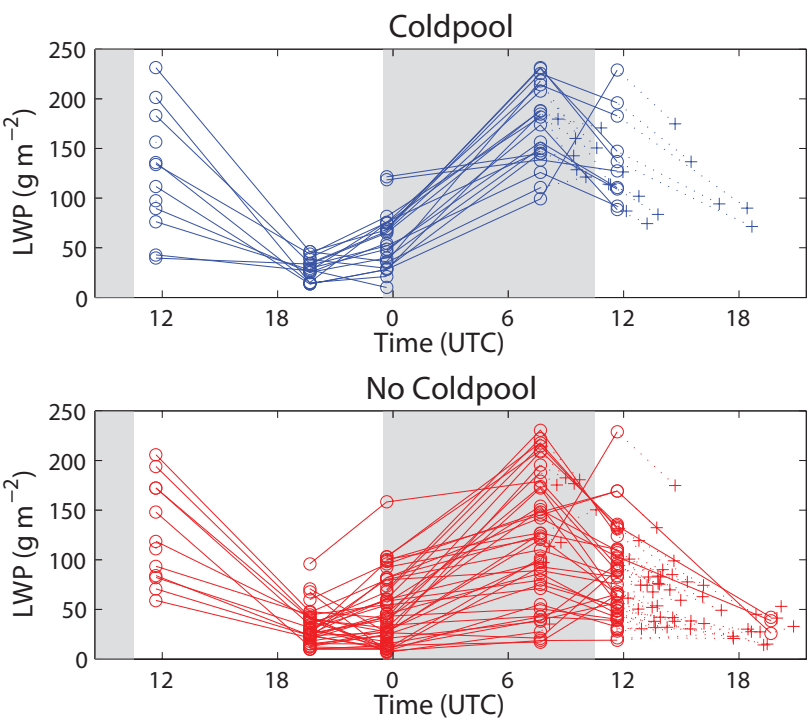

Fig. 10. Two-degree box-averaged LWP of cloud field along the ECMWF-derived back trajectories flight legs with (blue) and without (red) cold pools. Averaged LWP (circles) are plotted against UTC to place the flight legs within the context of the diurnal cycle. The times of the flight legs are indicated by crosses. LWP values of the crosses are estimated by linearly interpolating satellite LWP retrievals taken before and after the flight legs. Local nighttime hours in the VOCALS REx region are indicated by gray shading.

ratio $\left(q_{\mathrm{v}}\right)$ increases inside the cold pool by approximately $0.5 \mathrm{~g} \mathrm{~kg}^{-1}$ (Fig. 11b and Table 1). An increase in $q_{\mathrm{v}}$ inside the cold pool is consistent with the findings of Jensen et al. (2000) and Comstock et al. (2007). The spatial scale of the sharp $q_{\mathrm{v}}$ and $\theta$ change is similar, lending confidence to the fact that our approach is able to capture the edge between two distinct air masses.

If drizzle evaporation is solely responsible for the $\theta$ and $q_{\mathrm{v}}$ jumps, then $\theta_{\mathrm{e}}$ would be conserved, such that $c_{\mathrm{p}} \Delta \theta=$ $-L \Delta q_{\mathrm{v}}$, where $c_{\mathrm{p}}$ is the specific heat of air, $L$ is the latent heat of vaporization of water, and $\Delta \theta$ and $\Delta q_{\mathrm{v}}$ indicate the $\theta$ and $q_{\mathrm{v}}$ difference between inside and outside of the cold pool. Figure $11 \mathrm{~b}$ clearly shows that $L \Delta q_{\mathrm{v}}$ exceeds $c_{\mathrm{p}} \Delta \theta$ by roughly a factor of three, confirming that drizzle evaporation is not the only process that determines the temperature and water vapor inside the cold pool. Another way of stating this is that $\theta_{\mathrm{e}}$ increases inside cold pools (Fig. 11c and Table 1). This is not a new finding as previous modeling and observational studies have reported increases of $\theta_{\mathrm{e}}$ inside marine stratocumulus cold pools (Jensen et al., 2000; Mechem and Kogan, 2003; Van Zanten and Stevens, 2005; Savic-Jovcic and Stevens, 2008). These studies have attributed the $\theta_{\mathrm{e}}$ increase to an increase in stability in the lower MBL. This shows that the enhanced $\theta_{\mathrm{e}}$ is likely a universal feature of cold pools found under stratocumulus. Because air inside the cold pool is colder and hence negatively buoyant compared to the environmental air, air inside the cold pool is mixed 

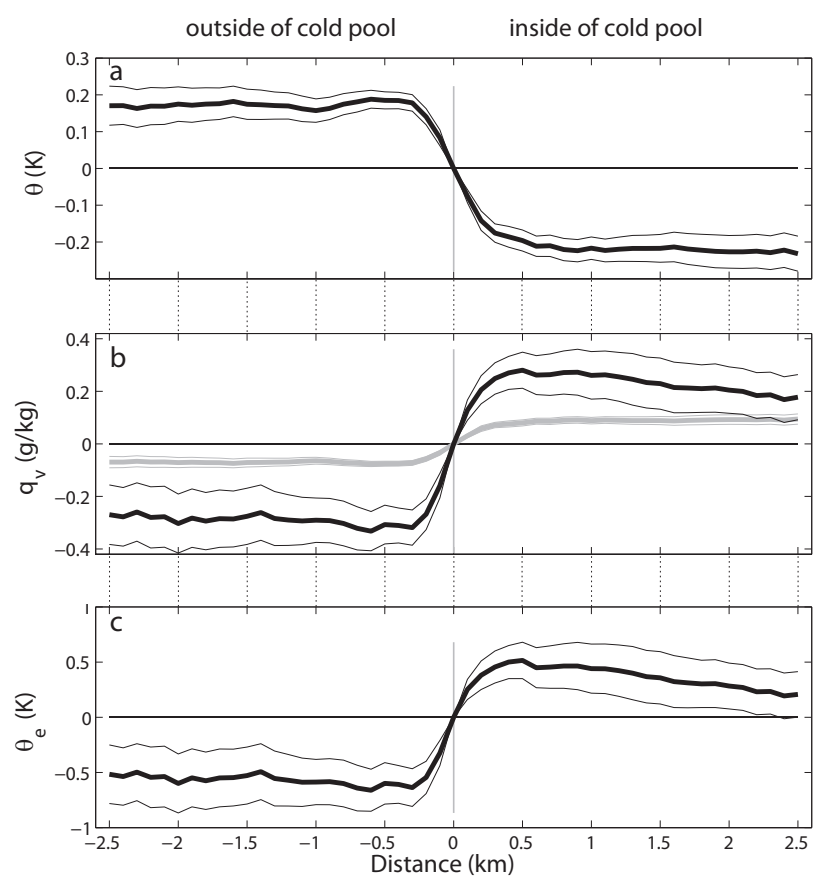

Fig. 11. Composite thermodynamic measurements of (a) potential temperature $(\theta)$, (b) water vapor mixing ratio $\left(q_{\mathrm{v}}\right)$, and (c) equivalent potential temperature $\left(\theta_{\mathrm{e}}\right)$ from 90 cold-pool edges. Anomalies relative to the value at the cold-pool edge are plotted. The air mass within the cold pool is found to the right of zero, while air mass outside of the cold-pool air mass is found to the left of zero. Bold lines indicate mean values, while thinner lines indicate the $95 \%$ confidence intervals of the mean, calculated using a standard Student $t$ test. The gray line in (b) indicates the change in $q_{\mathrm{v}}$ based on observed $\theta$ in the case where $c_{\mathrm{p}} \Delta \theta=-L \Delta q_{\mathrm{v}}$.

less efficiently with the rest of the MBL, allowing the energy from the surface fluxes to be trapped within a shallow layer close to the surface.

We also estimate the mean depth of the cold pools using the density jump across the cold-pool boundary, the radar altimetry data, and the pressure difference inside and outside of the cold pool. At the same altitude inside and outside of the cold pool, the denser air inside the cold pool will manifest itself as a positive pressure perturbation. We determine pressure perturbations by removing those due to small changes in aircraft altitude $z$ using the radar altimetry, and estimate the depth of the cold pool $h$ as

$h=z_{2}+\frac{p_{2}-\left[p_{1}+g \rho_{1}\left(z_{1}-z_{2}\right)\right]}{g\left(\rho_{2}-\rho_{1}\right)}$,

where $p$ is the in situ static pressure, $g$ is the gravitational acceleration, and $\rho$ is the in situ density. Subscripts 1 and 2 denote air outside and inside the cold pool, respectively. Taking the mean values of the observations made between the cold-pool edge and $2.5 \mathrm{~km}$ inside and $2.5 \mathrm{~km}$ outside of the cold pool, a mean cold-pool depth of $335 \pm 108 \mathrm{~m}$ is determined, where the error indicates the $95 \%$ confidence interval
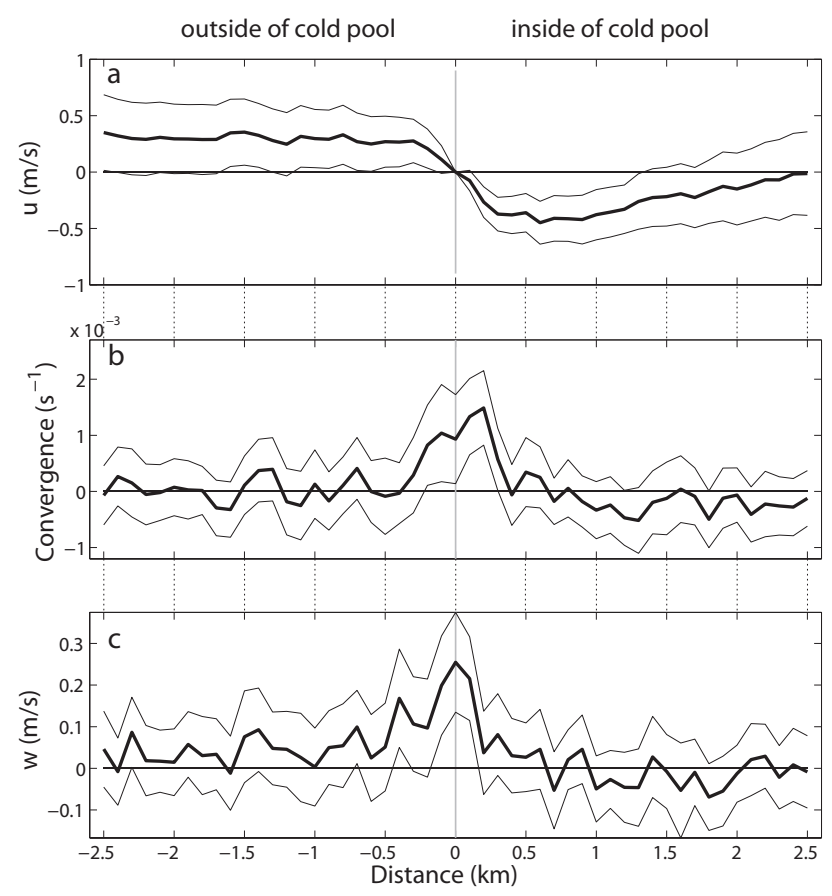

Fig. 12. Composites of dynamic measurements of (a) along-track wind speed $(u)$, (b) convergence calculated from $u$, and (c) vertical wind speed $(w)$ across 90 cold-pool edges. Bold lines indicate mean values, while thinner lines indicate the $95 \%$ confidence intervals of the mean, calculated using a standard Student $t$ test. For $u$ in (a), anomalies from the value at the cold-pool edge are composited and plotted, while for convergence and $w$ in (b and $\mathbf{c}$ ) they are not. The $4 / \pi$ correction factor is not applied to any of these plots.

in the mean value determined from the $95 \%$ confidence interval in $\rho$ and $p$. Because the background variations in $p$ are larger than the contribution from the cold pool, $p$ is not always greater inside the cold pool on every flight leg, and if we attempt to calculate the cold-pool depth for each transect, we obtain estimates of negative depth. For this reason, we only estimate a mean depth based on mean $p$ here. Our estimated cold-pool depth lies within the range of depths observed in past studies $(300 \mathrm{~m}$ and $500 \mathrm{~m}$ in Jensen et al., 2000, 100 $200 \mathrm{~m}$ from Fig. 10 in Comstock et al., 2007, and 200-300 m from Fig. $2 \mathrm{~d}$ in Feingold et al., 2010). Later in this paper, we use the cold-pool depth to quantify the impact of the surface stable layer in trapping surface fluxes.

\subsection{Dynamics}

The cold-pool air is denser than the environmental air, having a virtual potential temperature approximately $0.3 \mathrm{~K}$ lower than the environment. The cold pool therefore spreads out as a density current along the surface. The result is convergence at the cold-pool edge. To estimate this convergence, the along-track wind speed (wind speed along the direction of the flight track) is composited across the edge and 
Table 1. MBL characteristics, the mean values across the cold-pool edge, and when applicable, the $2.5 \mathrm{~km}$ mean differences inside and outside the cold pools. Only significant changes are listed.

\begin{tabular}{|c|c|c|c|}
\hline Variable & Value & Change \pm uncertainty & Time scale \\
\hline$\theta(\mathrm{K})$ & 288.6 & $-0.38 \pm 0.05$ & $1.5 \mathrm{~h}^{\mathrm{a}}$ \\
\hline$q_{\mathrm{v}}\left(\mathrm{gkg}^{-1}\right)$ & 8.8 & $0.51 \pm 0.10$ & $1.5 \mathrm{~h}^{\mathrm{a}}$ \\
\hline$\theta_{\mathrm{e}}(\mathrm{K})$ & 312.2 & $0.92 \pm 0.22$ & $1.5 \mathrm{~h}^{\mathrm{a}}$ \\
\hline CDP concentration $\left(\mathrm{cm}^{-3}\right)$ & 0.13 & $0.07 \pm 0.03$ & 17 or $23 \mathrm{~min}^{\mathrm{b}}$ \\
\hline DMS concentration (pptv) & 47.9 & $3.6 \pm 1.5$ & $29 \min ^{\mathrm{c}}$ \\
\hline$u\left(\mathrm{~ms}^{-1}\right)^{\mathrm{d}}$ & - & $0.49 \pm 0.30$ & - \\
\hline wind speed $\left(\mathrm{ms}^{-1}\right)^{\mathrm{e}}$ & 8.8 & - & - \\
\hline$\frac{\mathrm{d} u}{\mathrm{~d} x}\left(\mathrm{~s}^{-1}\right)^{\mathrm{f}}$ & $9.1 \times 10^{-4}$ & - & - \\
\hline$w\left(\mathrm{~ms}^{-1}\right)^{\mathrm{g}}$ & 0.25 & - & - \\
\hline Cold-pool depth (m) & $335 \pm 108$ & - & - \\
\hline Cloud thickness (m) & 640 & $130 \pm 40$ & - \\
\hline LCL (m) & 610 & $-161 \pm 27$ & - \\
\hline
\end{tabular}

${ }^{\text {a }}$ Estimated time scale necessary to reach observed differences in cold pools, calculated from simple box model differences driven by surface sensible and latent heat fluxes (see Sect. 4.4).

b Same as a , but using sea salt flux parameterizations from Gong (2003) and Clarke et al. (2006).

${ }^{\mathrm{c}}$ Same as ${ }^{\mathrm{a}}$, but using observed mean DMS flux from Yang et al. (2009).

${ }^{\mathrm{d}}$ Denotes wind speed along the direction of flight (see Sect 4.2). The $4 / \pi$ correction is not applied to the change.

e In situ horizontal wind speed measured at flight altitude $(\sim 150 \mathrm{~m})$.

${ }^{\mathrm{f}}$ Mean composite value at the cold-pool edge at flight altitude $(\sim 150 \mathrm{~m})$. The $4 / \pi$ correction is not applied to the change.

$\mathrm{g}$ Mean composite value at the cold-pool edge at flight altitude $(\sim 150 \mathrm{~m})$.

plotted in Fig. 12. The convergence at the cold-pool edge is calculated by taking the along track wind-speed difference from adjacent time steps. As was the case for cold-pool size (Sect. 3.1), the along track wind speed is expected to underestimate the true cold-pool outflow velocity by a factor of $4 / \pi$, because the flight track is not always aligned normal to the edge of the cold pool. The estimated convergence with the correction is $1.2 \times 10^{-3} \pm 1.0 \times 10^{-3} \mathrm{~s}^{-1}$ at the cold-pool edge. In Fig. 12b, the correction is not applied. Figure $12 \mathrm{~b}$ shows that the maximum convergence occurs $\sim 0.2 \mathrm{~km}$ inside the cold pool, with a corrected value of $1.9 \times 10^{-3} \mathrm{~s}^{-1}$.

We can then compare the corrected convergence we observe with the theoretical outflow velocity $V_{\mathrm{f}}$ at the edge of a density current:

$$
V_{\mathrm{f}}=k\left(\frac{g h \Delta \rho}{\rho}\right)^{\frac{1}{2}},
$$

where $k$ is the Froude number, $h$ is the cold-pool depth, $\Delta \theta$ is the density difference inside and outside of the cold pool, and $\rho$ is the environmental density. If we use the maximumcorrected outflow difference between inside and outside of the cold pool $\left(0.97 \mathrm{~m} \mathrm{~s}^{-1}\right)$, we obtain a $k$ value of 0.53 . This lies on the lower end of $k$ values reported in past studies of density currents acquired from lab experiments and observations of gust fronts and sea breezes (Table 8 of Wakimoto, 1982). Since $k$ represents the ratio of the inertial force to the gravitational force, this suggests that for the observed cold pools, whose density differences with the environment are smaller than those summarized by Wakimoto (1982), a smaller fraction of the potential energy from the density difference is converted into the propagation speed of the density current.

The aircraft-measured vertical wind tracks the convergence at the cold-pool edge extremely well (Fig. 12b and $\mathrm{c}$ and Table 1), with a mean updraft of $0.2-0.3 \mathrm{~m} \mathrm{~s}^{-1}$ that is $\sim 400 \mathrm{~m}$ wide straddling the cold-pool edge. In the composite mean, there is no systematic ascent or descent away from the edge, but it should be noted that the vertical wind anomaly exists in a background where the standard deviation of vertical wind speed is $0.37 \mathrm{~m} \mathrm{~s}^{-1}$. The updraft at the coldpool edge is consistent with both observational (Jensen et al., 2000) and modeling (Wang and Feingold, 2009) studies that show positive vertical wind anomalies at cold-pool edges. This lifting from the horizontal convergence at the cold-pool edge can potentially help lift warm moist air from the surface into the cloud layer to help maintain a steady source of moist air into the precipitating clouds.

\subsection{Cloud and precipitation}

In Sect. 3.3 we showed that at scales of $10-100 \mathrm{~km}$, cold pools preferentially formed under heavier precipitation and thicker clouds. We now examine whether the same changes in cloud and precipitation properties also occur across the cold-pool edges at the $1 \mathrm{~km}$ scale, using retrievals from the Wyoming Cloud Lidar (WCL), Wyoming Cloud Radar (WCR), and the G-band Radiometer Probe (GVR). First, there is no discernible change in mean cloud top height across the cold-pool edge (Fig. 13a). The mean cloud top height over cold-pool legs is approximately $300 \mathrm{~m}$ deeper 


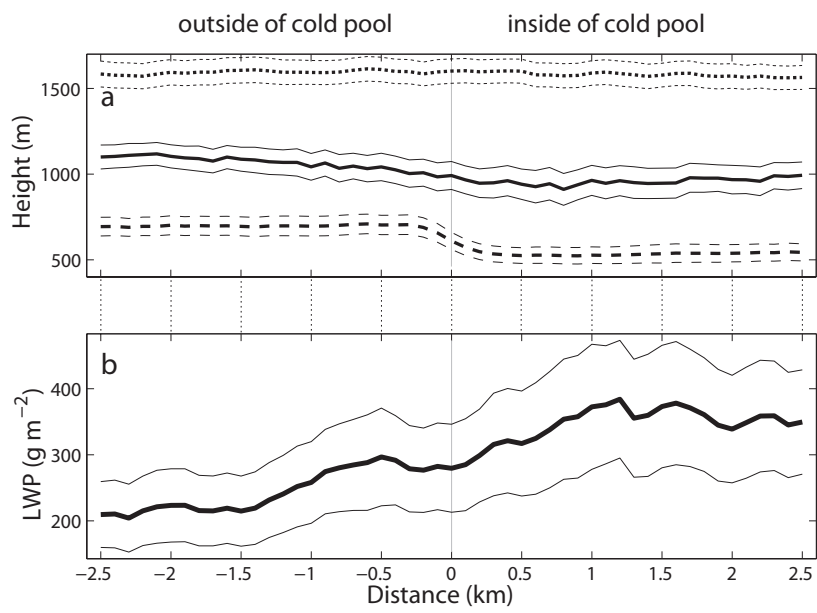

Fig. 13. Composites of cloud properties: (a) cloud top height (dotted), cloud base height (solid), and lifting condensation level (LCL; dashed); (b) cloud LWP retrieved by the GVR. The variables in (a and $\mathbf{b}$ ) are composited without taking the anomalies in relation to the cold-pool edge. Bold and thin lines are mean and $95 \%$ confidence intervals of the mean.

than the mean cloud top height derived from all the subcloud legs in REx (see Fig. 8), but this largely reflects the fact that air masses with cold pools are generally found in the deeper boundary layer in the west of the domain. On the other hand, the cloud base is approximately $100 \mathrm{~m}$ lower over the cold pool than it is outside (Fig. 13a), which results in the LWP increasing from approximately 250 to $350 \mathrm{~g} \mathrm{~m}^{-2}$ inside the cold pool (Fig. 13b). From the composites alone we cannot conclude that the decrease in cloud base height over the cold pool is a sign of the dynamical impact that cold pools have on the clouds. Because cold pools tend to form under heavier precipitation, the thickening that we see may just indicate that cold pools form under thicker clouds that tend to precipitate more.

Figure 13a also shows that the lifting condensation level (LCL) dramatically decreases inside the cold pool, evidence of the cooler and moister subcloud layer in the cold pool. Furthermore, we can assess the relative importance of the cooling and moistening inside the cold pool in explaining the decrease in LCL. To quantify the effects of $q_{\mathrm{v}}$ variations on the LCL variations, we fix the temperature from each transect across the leg to the value at the edge and then calculate the LCL based on the temperature at the edge and the $q_{\mathrm{v}}$ variations across the edge. The same is done to quantify the effect of temperature variations on the LCL variations. Of the $161 \mathrm{~m}$ difference in the LCL between the $2.5 \mathrm{~km}$ segment inside and outside of the cold pool, $113 \mathrm{~m}$ can be explained by $q_{\mathrm{v}}$ variations, while $48 \mathrm{~m}$ can be explained by the temperature variations. The mean LCL also lies more than $200 \mathrm{~m}$ below the mean cloud base height, even outside of the cold pool. Thus cold pools are generally found in decoupled MBLs and have the potential to lift the decoupled surface layer above

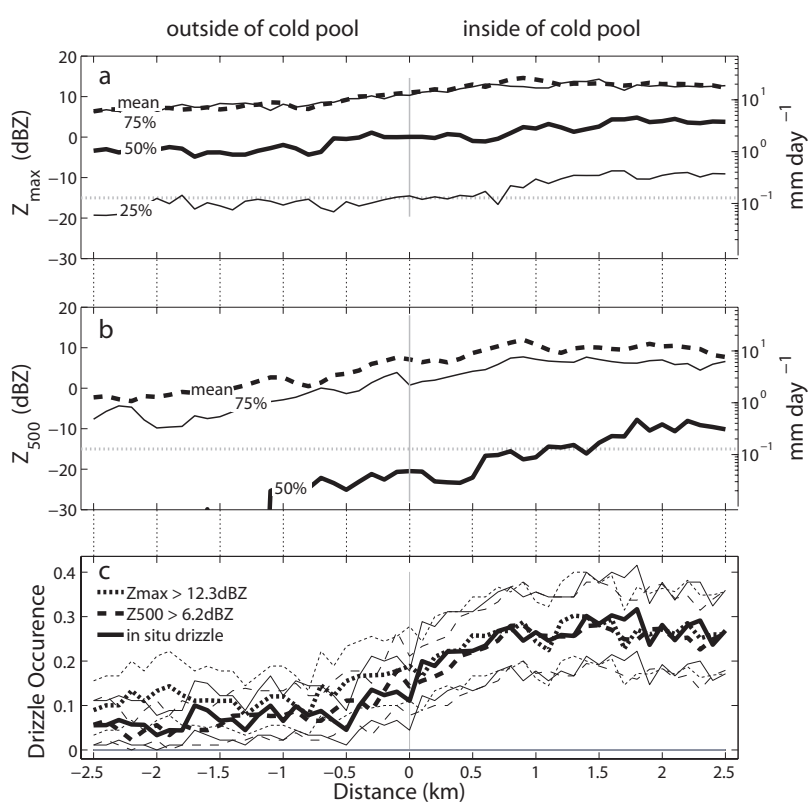

Fig. 14. Composites of (a) column maximum reflectivity $\left(Z_{\max }\right)$, (b) reflectivity at $500 \mathrm{~m}\left(Z_{500}\right)$, (c) the occurrence of subcloud 98th percentile precipitation rates across the cold-pool edge at each of the three different levels: at altitude of $Z_{\max }$ (dotted), at $500 \mathrm{~m}$ (dashed), and at flight level (solid). For (a and b), dotted lines indicate mean values, bold solid lines indicate median values, and thin solid lines indicate 25 th and 75 th percentile values. The 25 th, 50 th, and 75th percentile values are shown instead of the mean and the $95 \%$ confidence intervals, since the radar reflectivity does not follow a Gaussian distribution. This can be easily noted from the mean reflectivity (dashed) lying far above the median value (solid bold). Previously used $-15 \mathrm{dBZ}$ threshold for drizzle occurrence is noted by a dotted gray line. In (c), the mean values and the $95 \%$ confidence interval are calculated using bootstrap resampling (Efron and Gong, 1983) of the mean occurrence over 1000 iterations.

its LCL to form cumulus clouds that can penetrate into the overlying stratocumulus.

To examine precipitation characteristics in and below the clouds, we composite radar reflectivity from the Wyoming Cloud Radar (WCR). From Fig. 14a, which shows the $Z_{\max }$ composite, we can see that a majority of the columns exceed the $-15 \mathrm{dBZ}$ threshold that we use to distinguish drizzling from non-drizzling clouds (Bretherton et al., 2010). Since the altitude of $Z_{\max }$ largely corresponds to the cloud base height (Sect. 2.1; Wood et al., 2011a), $Z_{\max }$ largely indicates the cloud base precipitation rate. Previous studies report using threshold values ranging between -20 and $-10 \mathrm{dBZ}$ (Liu et al., 2008). Regardless of the choice of threshold, we can see that a majority of the clouds across the cold-pool edge are drizzling, and that there is a gradual increase in precipitation over the cold pool. However, there is a more abrupt increase across the cold-pool edge in radar reflectivity below the mean cloud base at $500 \mathrm{~m}$ altitude, showing that precipitation rates at $500 \mathrm{~m}$ are better indicators of cold-pool 
formation (Fig. 14b). At the flight level $(\sim 150 \mathrm{~m})$, there is a three-fold increase in drizzle occurrence inside the cold pool (Fig. 12c). Drizzle occurrence at the flight level is defined as a drizzle water content $>0.02 \mathrm{~g} \mathrm{~m}^{-3}$ as measured by the 2DC probe, which corresponds to the 98th percentile of all drizzle water contents observed by the C-130 at $150 \mathrm{~m}$. To compare the occurrence of similarly infrequent precipitation rates at the other two levels, the occurrence of 98 th percentile precipitation rates at $500 \mathrm{~m}$ and column maximum are also plotted in Fig. 14c. The drizzle occurrence at $500 \mathrm{~m}$ also increases three-fold over the cold pool, but the occurrence of $Z_{\max }$ only increases by two-fold inside the cold pool, supporting our previous observation that precipitation occurrence lower in the MBL is a better indicator of coldpool formation.

\subsection{Aerosols and DMS}

In Sect. 4.1 we discussed the increase in $\theta_{\mathrm{e}}$ inside the cold pools, which previous studies have attributed to the trapping of surface fluxes within the cold pool. Both coarse mode (sea-spray) aerosols and dimethyl sulfide (DMS) have their primary sources at the ocean surface (Yang et al. (2009) for DMS; Blot et al. (2013) for coarse-mode aerosols). If aerosol and DMS concentrations show similar increases inside the cold pools it would lend support to the trapping hypothesis for increased $\theta_{\mathrm{e}}$ inside cold pools. We use measurements from the Passive Cavity Aerosol Spectrometer Probe (PCASP) for aerosol concentrations in the accumulation mode and the Cloud Droplet Probe (CDP) for concentrations in the coarse mode. Aerosol concentrations from 43 edges are used to create the PCASP composite, and aerosol concentrations from 38 edges are used to create the CDP composite. These numbers are substantially lower than the 90 edges used to calculate composites of other variables because aerosol measurements from possible drizzle shattering cases are removed and aerosol measurements are unavailable for two of the research flights due to instrument malfunctions. The composites of both PCASP- and CDP-measured aerosol concentrations increase inside the cold pool (Fig. 15a), but the relative magnitude of the increase is substantially greater for the coarse particles. The mean concentration $2.5 \mathrm{~km}$ inside the cold pool exceeds that of the mean concentration $2.5 \mathrm{~km}$ outside the cold pool, by only $7 \%\left(98\right.$ to $\left.106 \mathrm{~cm}^{-3}\right)$ for the PCASP, but by $70 \%\left(0.09\right.$ to $\left.0.16 \mathrm{~cm}^{-3}\right)$ for the CDP (see Table 1). The increase in PCASP aerosol concentration is not significant at the $95 \%$ level, whereas the increase in CDP aerosol concentration is. Because the CDP measures the particles in ambient air, we must account for the increased number of CDP-measured aerosols purely due to the increase in RH in the cold pool (from $71 \%$ to $78 \%$ ). Assuming that the particles have a growth factor similar to sodium chloride (Tang, 1996), the increased swelling of the aerosols in cold pools can explain $0.01 \mathrm{~cm}^{-3}$ of the $0.07 \mathrm{~cm}^{-3}$ increase in CDP aerosol concentration in cold pools. Along with the
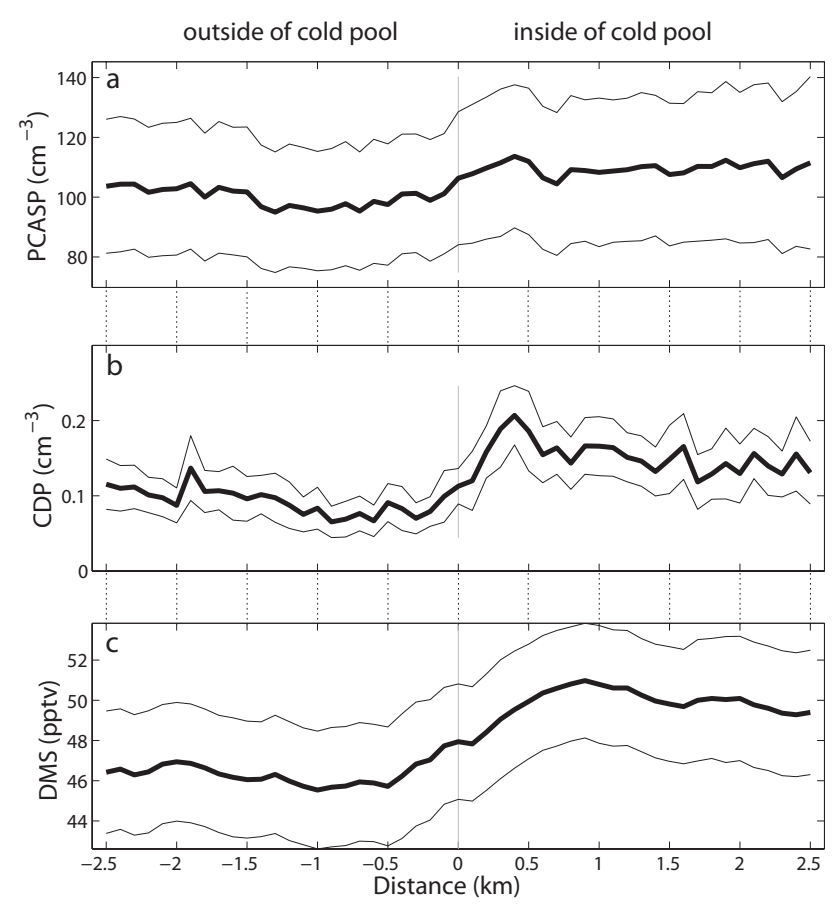

Fig. 15. Composites of (a) PCASP-measured aerosol concentration $(0.1 \mu \mathrm{m}<D<3 \mu \mathrm{m})$, (b) CDP-measured aerosol concentration $(D>1 \mu \mathrm{m})$, and (c) dimethyl sulfide (DMS) concentration. All variables are composited without taking the anomalies in relation to the cold-pool edge. Bold and thin lines are mean and $95 \%$ confidence intervals of the mean.

coarse mode aerosol concentration, the mean DMS concentration also increases across the cold-pool edge (Fig. 15c and Table 1). Taken together, the enhancements in CDPmeasured aerosols and DMS inside the cold pools suggest the effect of cold-pool-induced stratification in trapping surface fluxes.

\subsection{Two box model}

To test whether the capping of surface fluxes by the coldpool-induced stratification can account for enhancements in coarse mode aerosol and DMS concentrations inside the cold pool, we employ a set of two simple box models with different vertical extents to study the differences in coarse mode aerosol and DMS concentration inside and outside of cold pools. We are interested in testing whether the differences can be obtained over time scales comparable to the lifetime of cold pools. Previous studies have established that the majority of coarse mode aerosols in the MBL come from the sea salt flux at the ocean surface and that they are strongly dependent on wind speed (Gong, 2003; Clarke et al., 2006; O'Dowd and de Leeuw, 2007). One box represents a column of air outside of the cold pool, and the other represents the air inside the cold pool; the two boxes of different heights over which the surface fluxes are mixed. Two sea 
salt parameterizations from Gong (2003) and Clarke et al. (2006) are used to explore sensitivity to different sea salt flux parameterizations. To drive the sea salt fluxes, we use $10 \mathrm{~m}$ wind speeds by taking the $\mathrm{C}-130$ observed mean wind speeds and interpolating them down to the surface by assuming a log-wind profile with a surface roughness of $1.86 \times 10^{-4} \mathrm{~m}$ (Wood et al., 2011a). Although wind speeds increase slightly in the cold pool ( 8.35 to $8.45 \mathrm{~m} \mathrm{~s}^{-1}$ ), we find that this has a negligible effect on the sea salt fluxes. Because the CDP measured aerosols in ambient relative humidity and because MBL aerosols in this region are mostly hygroscopic (Allen et al., 2011), we account for the hygroscopic growth of the measured aerosols by estimating the dry diameters of the measured aerosols using the hygroscopic growth factor of sodium chloride from Tang (1996). For the DMS flux, we use a previously observed mean flux estimate from the VOCALS region (Yang et al., 2009).

The aircraft measurements provide no direct knowledge of the temporal evolution of cold pools, and so we must make a number of assumptions in our model. First, we assume that the cold-pool forms instantaneously at $t=0$ and that there is no difference in the concentrations prior to cold-pool formation. Second, we assume that the heights of the two boxes are fixed in time. Third, we assume that the only exchange determining changes in aerosol and DMS concentrations in the boxes are due to surface fluxes. Therefore, differences in the rate at which concentrations increase inside the two boxes will be driven by differences in the height of the two boxes.

Using Eq. (7) for estimating the depth of the cold pool, we obtain a height of $226 \mathrm{~m}$ for the box representing the cold pool. This depth is lower than the previous estimate of $335 \mathrm{~m}$, because here we are estimating the mean cold-pool depth only for those legs in which CDP measurements are available. For the second box, a mixing height of $1171 \mathrm{~m}$ is used, derived using the following basis. The mixing height of a well-mixed MBL corresponds to the cloud top height, whereas the mixing height of a decoupled MBL is generally below stratocumulus cloud base (Jones et al., 2011). In the latter, the lifting condensation level (LCL) does not correspond to the stratocumulus cloud base, because $\theta$ is higher and $q_{\mathrm{v}}$ is lower in the cloud layer than in the surface layer. We define a decoupled MBL in this analysis as a MBL where the difference between the cloud base height and the LCL is greater than $300 \mathrm{~m}$ (Comstock et al., 2005). We take the LCL as the mixing height in decoupled cases and the cloud top height as the mixing height for the coupled MBLs. The mean of these weighted by the frequency of occurrence of coupled and decoupled MBLs is used to estimate the mixing height of $1171 \mathrm{~m}$ for the second box.

We find that the observed concentration difference of aerosols in the CDP size range is reached in $17 \mathrm{~min}$ using the parameterization of Clarke et al. (2006) and 23 min using that of Gong (2003). Similarly the DMS enhancement inside the cold pool, using the mean DMS flux of $3.2 \mu$ moles $\mathrm{m}^{-2} \mathrm{~d}^{-1}$ in the VOCALS region as reported by Yang et al. (2009) is reached in $29 \mathrm{~min}$. We take the good agreement in the time scales for coarse aerosols and DMS as evidence that trapping may be the critical process governing the build-up of scalar quantities in the stable air in cold pools. Jensen et al. (2000) using a mixed layer model estimate that it takes approximately $3.5 \mathrm{~h}$ for the cold pool to lose its thermodynamic identity due to surface fluxes and mixing. Therefore, both the enhancements in aerosol and DMS concentrations can be explained by the trapping of surface fluxes by the cold pool. The time scales also give us an estimate of the "mean" age of the observed cold pools. Since we observe that the cold pools spread out at a mean velocity of $\sim 1 \mathrm{~m} \mathrm{~s}^{-1}$ (Fig. 13a), this indicates that the mean cold pool has likely spread out a mean distance of approximately $1-2 \mathrm{~km}$ on either side at the time of sampling.

Attempting to estimate the time scale necessary to explain the enhanced $\theta_{\mathrm{e}}$ in the cold-pool surface layer is complicated by the dependence of the surface fluxes on the temperature and humidity of the air inside the cold pool. The fluxes cannot be considered constant inside and outside the cold pool as we have assumed for the aerosol and DMS fluxes, where we found that the difference in the wind speed, the main driver of the two fluxes, to be negligible inside and outside the cold pool. We must make the additional assumption that the cold-pool air is initially cooled and moistened at $t=0$ by the spontaneous evaporation of drizzle water into the air. If we make these assumptions and use observed SST and wind speed to drive the two box model, we obtain a time scale of $1.5 \mathrm{~h}$. This is at least a factor of 3 times longer than the time scales estimated from the sea salt or DMS flux. Given the strong sensitivity of the surface fluxes to the surface air properties, we cannot make any definitive statements as to whether stratification alone explains the enhancement of $\theta_{\mathrm{e}}$ in the cold pool. What we can say is that the enhancement of $\theta_{\mathrm{e}}$ is likely largely dominated by latent heat fluxes.

\section{Discussion and conclusions}

Modeling and observational studies have suggested that cold pools initiate transitions from closed to open cellular stratocumulus clouds (Savic-Jovcic and Stevens, 2008; Xue et al., 2008; Wang and Feingold, 2009; Feingold et al., 2010; Berner et al., 2011). This study systematically examines cold pools that form in the southeast Pacific using aircraft data collected during VOCALS-REx. We first examined the range of MBL and cloud conditions that accompany cold pools, finding that cold pools form preferentially under heavily drizzling clouds $\left(>1 \mathrm{mmd}^{-1}\right)$. This explains why cold pools are common further offshore where the MBL is deeper, clouds are thicker, and the aerosol concentrations are lower. Satellite microwave data show high values of cloud LWP during the night prior to the observed cold pools, but do not show high values of LWP during the previous afternoon. This suggests that understanding the factors controlling how high values of 


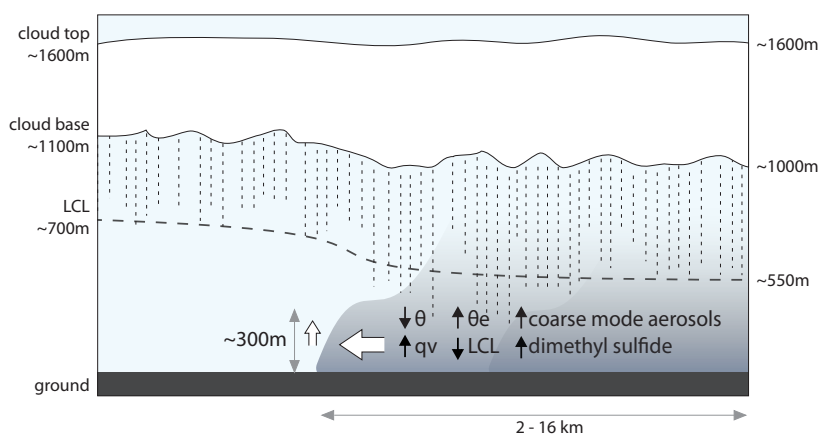

Fig. 16. Schematic showing the main properties of the cold pools identified in this study.

LWP are produced overnight over relatively short periods of time will be important for predicting cold-pool formation. In terms of size, the observed cold pools in this study have horizontal extents that are roughly log-normally distributed with the central 50th percentile between 2 and $16 \mathrm{~km}$. Some cold pools are larger than $100 \mathrm{~km}$ and these tend to be associated with cold pools clustered and embedded in other cold pools, as is commonly found within POCs. Instead of forming separately, cold pools tend to cluster together with new ones often forming on top of older ones, stressing the importance of understanding how cold pools interact with each other to affect boundary-layer processes.

Although we have examined the MBL conditions that correlate with cold-pool occurrence, we are limited by single snapshots from the time of cold-pool sampling and have not addressed the relationship between cold-pool occurrence and large-scale parameters, such as tropospheric temperatures, sea surface temperatures, and subsidence rates, which all act to modify the geographic and temporal variations in MBL depth and conditions over the VOCALS region. Because cold pools preferentially form where large-scale meteorology favors the stratocumulus-to-cumulus transition, it remains to be seen whether and to what extent the cold pools play a role in the cloud break-up.

Composites of cold-pool edges show that numerous variables change between the cold-pool air and its environment, as summarized in Table 1 and conceptually in Fig. 16. Whereas the analysis of leg-averages shows that cold pools tend to form under heavier precipitation $\left(>1 \mathrm{mmd}^{-1}\right)$, the composites further demonstrate that precipitation near the surface is a better indicator of cold-pool formation than precipitation at cloud base. Unlike in the analysis of legaverages, however, we do not see a substantial change in the composite of cloud top height across cold-pool edges, showing that not all large-scale parameters that make the MBL prone to cold-pool formation are reflected in the changes at smaller spatial scales. The composites do show that, consistent with previous measurements of cold pools under marine stratocumulus, drops in temperature are accompanied by in- creased water vapor, convergence and associated uplift at the edges, and enhanced $\theta_{\mathrm{e}}$ values inside the cold pool. Additionally, we find an increase in DMS and coarse-mode aerosol concentrations, both of which provide observational clues that cold-pool-induced stratification concentrates the products of surface fluxes in the cold air near the surface. From the observations alone, we cannot address whether the dynamic or thermodynamic effects of the cold pools are more important for changing MBL structure. We do find, however, that the significant drop in LCL inside the cold pool is largely due to the $q_{\mathrm{v}}$ increases instead of the $\theta$ decreases. This means that if cold pools form where clouds are thicker and cloud bases are lower due to lower LCL, then the lowered cloud bases are a result of the cold pool trapping surface fluxes near the surface. The modeling study of Savic-Jovcic and Stevens (2008) points out the importance of cold pools in transitioning from closed-cell to open-cell convection. Furthermore, the dynamic and thermodynamic effects of the cold pool can be thought of as how cold pools vertically and horizontally concentrate moisture (thermodynamic) and how this is lifted into the cloud layer (dynamic). Unlike cold pools that form under deeper cumulonimbus clouds (Goff, 1976), wind gusts associated with the cold pools under stratocumulus are almost always much smaller than the mean wind speed in the SEP. This means that, by themselves, cold pools cannot drive upstream propagation of POC boundaries (Fig. 2 of Wood et al., 2011a). This also means that changes in surface fluxes inside the cold pool that are driven by changes in wind speed are small.

There remain a number of questions that cannot be addressed from observations alone. We find that cold pools indeed exert dynamic and thermodynamic effects on the MBL. What then is their role in organizing and influencing further precipitation? Is the observed clustering of cold pools just an imprint of environmental conditions, or do cold pools play a role in the clustering? Can the dynamic effect of cold pools alone increase precipitation in a cloud field? Modeling studies of Xue et al. (2008), Feingold et al. (2010), and Wang et al. (2010) have tackled this using a variety of experiments, but it remains to be seen whether a dynamic or thermodynamic feedback between precipitation and cold pools is necessary to transition from overcast stratocumulus to one of broken cumulus clouds.

Acknowledgements. Funding for this work was provided by NSF (ATM-0745702 and AGS-1242639). The authors thank the scientists, staff, ground crew and aircrew at the NCAR Research Aviation Facility, and the C-130 scientists who were instrumental in the collection of the data analyzed here. The C-130 data were provided by NCAR/EOL under sponsorship of the National Science Foundation. http://data.eol.ucar.edu/. AMSR-E data are produced by Remote Sensing Systems and sponsored by the NASA Earth Science MEaSUREs DISCOVER Project and the AMSR-E Science Team. WindSat data are produced by Remote Sensing Systems and sponsored by the NASA Earth Science 
MEaSUREs DISCOVER Project and the NASA Earth Science Physical Oceanography Program. SSM/I data are produced by Remote Sensing Systems and sponsored by the NASA Earth Science MEaSUREs DISCOVER Project. AMSR-E, WindSat, and SSM/I data are available at http://www.remss.com. The authors thank Anthony Clarke, Romain Blot, Jorgen Jensen, Sandra Yuter, Robert Houze, and Christopher Bretherton for fruitful discussions on various aspects of the study. Rhea George and Gallia Painter are thanked for providing the code and help to run the forward and backward trajectories.

Edited by: B. Albrecht

\section{References}

Allen, G., Coe, H., Clarke, A., Bretherton, C., Wood, R., Abel, S. J., Barrett, P., Brown, P., George, R., Freitag, S., McNaughton, C., Howell, S., Shank, L., Kapustin, V., Brekhovskikh, V., Kleinman, L., Lee, Y.-N., Springston, S., Toniazzo, T., Krejci, R., Fochesatto, J., Shaw, G., Krecl, P., Brooks, B., McMeeking, G., Bower, K. N., Williams, P. I., Crosier, J., Crawford, I., Connolly, P., Allan, J. D., Covert, D., Bandy, A. R., Russell, L. M., Trembath, J., Bart, M., McQuaid, J. B., Wang, J., and Chand, D.: South East Pacific atmospheric composition and variability sampled along $20^{\circ} \mathrm{S}$ during VOCALS-REx, Atmos. Chem. Phys., 11, 5237-5262, doi:10.5194/acp-11-5237-2011, 2011.

Berner, A. H., Bretherton, C. S., and Wood, R.: Large-eddy simulation of mesoscale dynamics and entrainment around a pocket of open cells observed in VOCALS-REx RF06, Atmos. Chem. Phys., 11, 10525-10540, doi:10.5194/acp-11-10525-2011, 2011.

Blot, R., Clarke, A. D., Freitag, S., Kapustin, V., Howell, S. G., Jensen, J. B., Shank, L. M., McNaughton, C. S., and Brekhovskikh, V.: Ultrafine sea spray aerosol over the southeastern Pacific: open-ocean contributions to marine boundary layer CCN, Atmos. Chem. Phys., 13, 7263-7278, doi:10.5194/acp-137263-2013, 2013.

Bolton, D.: The computation of equivalent potential temperature, Mon. Weather Rev., 108, 1046-1053, 1980.

Bretherton, C. S., Wood, R., George, R. C., Leon, D., Allen, G., and Zheng, X.: Southeast Pacific stratocumulus clouds, precipitation and boundary layer structure sampled along $20^{\circ} \mathrm{S}$ during VOCALS-REx, Atmos. Chem. Phys., 10, 10639-10654, doi:10.5194/acp-10-10639-2010, 2010.

Burleyson, C. D., deSzoeke, S. P., Yuter, S. E., Wilbanks, M., and Brewer, W. A.: Ship-based observations of the Diurnal Cycle of Southeast Pacific Marine Stratocumulus Clouds and Precipitation, J. Atmos. Sci., in press, doi:10.1175/JAS-D-13-01.1, 2013.

Charba, J.: Application of gravity current model to analysis of squall-line gust front, Mon. Weather Rev., 102, 140-156, 1974.

Clarke, A. D., Owens, S. R., and Zhou, J.: An ultrafine sea-salt flux from breaking waves: implications for cloud condensation nuclei in remote marine atmosphere, J. Geophys. Res., 111, 06202, doi:10.1029/2005JD006565, 2006.

Coakley, J. A. and Bretherton, F. P.: Cloud cover from highresolution scanner data: detecting and allowing for partially filled fields of view, J. Geophys. Res., 87, 4917-4932, doi:10.1029/JC087iC07p04917, 1982.

Comstock, K. K., Wood, R., Yuter, S. E., and Bretherton, C. S.: Reflectivity and rain rate in and below drizzling stratocumulus, Q. J.
Roy. Meteor. Soc., 130, 2891-2918, doi:10.1256/qj.03.187, 2004.

Comstock, K. K., Bretherton, C. S., and Yuter, S. E.: Mesoscale variability and drizzle in Southeast Pacific stratocumulus, J. Atmos. Sci., 62, 3792-3807, doi:10.1175/JAS3567.1, 2005.

Comstock, K. K., Yuter, S. E., Wood, R., and Bretherton, C. S.: The three-dimensional structure and kinematics of drizzling stratocumulus, Mon. Weather Rev., 135, 3767-3784, doi:10.1175/2007MWR1944.1, 2007.

Droegemeier, K. K. and Wilhelmson, R. B.: Numerical simulation of thunderstorm outflow dynamics. I: Outflow sensitivity experiments and turbulence dynamics, J. Atmos. Sci., 44, 1180-1210, doi:10.1175/1520-0469(1987)044<K1180:NSOTOD>2.0.CO;2, 1987.

Efron, B. and Gong, G.: A leisurely look at the bootstrap, the jackknife, and cross-validation, Am. Stat., 37, 36, doi:10.2307/2685844, 1983.

Engerer, N. A., Stensrud, D. J., and Coniglio, M. C.: Surface characteristics of observed cold pools, Mon. Weather Rev., 13, 48394849, doi:10.1175/2008MWR2528.1, 2008.

Feingold, G., Koren, I., Wang, H., Xue, H., and Brewer, W. A.: Precipitation-generated oscillations in open cellular cloud fields, Nature, 466, 849-852, doi:10.1038/nature09314, 2010.

Geoffroy, O., Brenguier, J.-L., and Sandu, I.: Relationship between drizzle rate, liquid water path and droplet concentration at the scale of a stratocumulus cloud system, Atmos. Chem. Phys., 8, 4641-4654, doi:10.5194/acp-8-4641-2008, 2008.

George, R. C., Wood, R., Bretherton, C. S., and Painter, G.: Development and impact of hooks of high droplet concentration on remote southeast Pacific stratocumulus, Atmos. Chem. Phys., 13, 6305-6328, doi:10.5194/acp-13-6305-2013, 2013.

Goff, R. C.: Vertical structure of thunderstorm outflows, Mon. Weather Rev., 104, 1429-1440, 1976.

Gong, S. L.: A parameterization of sea-salt aerosol source function for sub- and super-micron particles, Global Biogeochem. Cy., 17, 1097, doi:10.1029/2003GB002079, 2003.

Hilburn, K. A. and Wentz, F. J.: Intercalibrated passive microwave rain products from the Unified Microwave Ocean Retrieval Algorithm (UMORA), J. Appl. Meteorol. Clim., 47, 778-794, doi:10.1175/2007JAMC1635.1, 2008.

Jensen, J. B., Lee, S., Krummel, P. B., Katzfey, J., and Gogoasa, D.: Precipitation in marine cumulus and stratocumulus. Part I: Thermodynamic and dynamic observations of closed cell circulations and cumulus bands, Atmos. Res., 54, 117-155, 2000.

Jones, C. R., Bretherton, C. S., and Leon, D.: Coupled vs. decoupled boundary layers in VOCALS-REx, Atmos. Chem. Phys., 11, 7143-7153, doi:10.5194/acp-11-7143-2011, 2011.

Khairoutdinov, M. F., Krueger, S. K., Moeng, C.-H., Bogenschutz, P. A., and Randall, D. A.: Large-Eddy simulation of maritime deep tropical convection, J. Adv. Mode. Earth Syst., 1, 13, doi:10.3894/JAMES.2009.1.15, 2011.

Leon, D. C., Wang, Z. and Liu, D.: Climatology of drizzle in marine boundary layer clouds based on 1 year of data from CloudSat and Cloud-Aerosol Lidar and Infrared Pathfinder Satellite Observations (CALIPSO), J. Geophys. Res., 113, D00A14, doi:10.1029/2008JD009835, 2008.

Liu, Y., Geerts, B., Miller, M., Daum, P., and McGraw, R.: Threshold radar reflectivitiy for drizzling clouds, Geophys. Res. Lett., 35, L03807, doi:10.1029/2007GL031201, 2008. 
Martin, G., Johnson, D., and Spice, A.: The measurement and parameterization of effective radius of droplets in warm stratocumulus clouds., J. Atmos. Sci., 51, 1823-1842, doi:10.1175/15200469(1994)051<1823:TMAPOE>2.0.CO;2, 1994.

Mechem, D. B. and Kogan, Y. L.: Simulating the transition from drizzling marine stratocumulus to boundary layer cumulus with a mesoscale model, Mon. Weather Rev., 131, 2342-2360, 2003.

O'Dowd, C. D. and de Leeuw, G.: Marine aerosol production: a review of the current knowledge, Philos. T. R. Soc. A, 365, 17531774, doi:10.1098/rsta.2007.2043, 2007.

Paluch, I. R. and Lenschow, D. H.: Stratiform cloud formation in the marine boundary layer, J. Atmos. Sci., 48, 2141-2158, 1991.

Rotunno, R., Klemp, J., and Weisman, M.: A theory for strong, long-lived squall lines, J. Atmos. Sci., 45, 463-464, 1988.

Savic-Jovcic, V. and Stevens, B.: The structure and mesoscale organization of precipitating stratocumulus, J. Atmos. Sci., 65, 15871605, doi:10.1175/2007JAS2456.1, 2008.

Seifert, A. and Heus, T.: Large-eddy simulation of organized precipitating trade wind cumulus clouds, Atmos. Chem. Phys., 13, 5631-5645, doi:10.5194/acp-13-5631-2013, 2013.

Sharon, T. M., Albrecht, B. A., Jonsson, H. H., Minnis, P., Khaiyer, M. M., van Reken, T. M., Seinfeld, J., and Flagan, R.: Aerosol and cloud microphysical characteristics of rifts and gradients in maritime stratocumulus clouds, J. Atmos. Sci., 63, $983-$ 997, doi:10.1175/JAS3667.1, 2006.

Srivastava, R. C.: A model of intense downdrafts drive by the melting and evaporation of precipitation, J. Atmos. Sci., 44, 1752-1773, doi:10.1175/15200469(1987)044<1752:AMOIDD>2.0.CO;2, 1987.

Stevens, B., Vali, G., Comstock, K., Wood, R., Van Zanten, M. C., Austin, P. H., Bretherton, C. S., and Lenschow, D. H.: Pockets of open cells and drizzle in marine stratocumulus, B. Am. Meteorol. Soc., 86, 51-57, doi:10.1175/BAMS-86-1-51, 2005.

Tang, I. N.: Chemical and size effects on hygroscopic aerosols on light scattering coefficients, J. Geophys. Res., 101, 1924519250, 1996.

Terai, C. R., Wood, R., Leon, D. C., and Zuidema, P.: Does precipitation susceptibility vary with increasing cloud thickness in marine stratocumulus?, Atmos. Chem. Phys., 12, 4567-4583, doi:10.5194/acp-12-4567-2012, 2012.

Tompkins, A. M.: Organization of tropical convection in low vertical wind shears: the role of cold pools, J. Atmos. Sci., 58, 1650-1672, doi:10.1175/15200469(2001)058<1650:OOTCIL>2.0.CO;2, 2001.

Toniazzo, T., Abel, S. J., Wood, R., Mechoso, C. R., Allen, G., and Shaffrey, L. C.: Large-scale and synoptic meteorology in the south-east Pacific during the observations campaign VOCALSREx in austral Spring 2008, Atmos. Chem. Phys., 11, 49775009, doi:10.5194/acp-11-4977-2011, 2011.

Van Zanten, M. C. and Stevens, B.: Observations of the structure of heavily precipitating marine stratocumulus, J. Atmos. Sci., 62, 4327-4342, 2005.

Wakimoto, R. M.: The life cycle of thunderstorm gust fronts as viewed with Doppler radar and rawinsonde data, Mon. Weather Rev., 110, 1060-1082, 1982.

Wang, H. and Feingold, G.: Modeling mesoscale cellular structure and drizzle in marine stratocumulus. Part I: Impact of drizzle on the formation and evolution of open cells, J. Atmos. Sci., 66, 3237-3256, doi:10.1175/2009JAS3022.1, 2009.
Wang, H., Feingold, G., Wood, R., and Kazil, J.: Modelling microphysical and meteorological controls on precipitation and cloud cellular structures in Southeast Pacific stratocumulus, Atmos. Chem. Phys., 10, 6347-6362, doi:10.5194/acp-10-6347-2010, 2010.

Wang, S. and Albrecht, B. A.: A stratocumulus model with an internal circulation., J. Atmos. Sci., 43, 2374-2391, doi:10.1175/1520-0469(1986)043<2374:ASMWAI>2.0.CO;2, 1986.

Wang, Z., Wechsler, P., Kuestner, W., French, J., Rodi, A., Glover, B., Burkhart, M., and Lukens, D.: Wyoming Cloud Lidar: instrument description and applications, Opt. Expres, 17, 1357613587, 2009.

Wentz, F.: A well-calibrated ocean algorithm for Special Sensor Microwave/Imager, J. Geophys. Res., 102, 8703-8718, doi:10.1029/96JC01751, 1997.

Wentz, F. and T. Meissner: AMSR ocean algorithm, Algorithm Theor. Basis Doc. 121599A-1, Remote Sens. Syst., Santa Rosa, CA, 2000.

Wood, R.: Stratocumulus clouds, Mon. Weather Rev., 140, 2373 2423, doi:10.1175/MWR-D-11-00121.1, 2012.

Wood, R. and Field, P. R.: The distribution of cloud horizontal sizes, J. Climate, 24, 4800-4816, doi:10.1175/2011JCLI4056.1, 2011.

Wood, R., Bretherton, C. S., Leon, D., Clarke, A. D., Zuidema, P., Allen, G., and Coe, H.: An aircraft case study of the spatial transition from closed to open mesoscale cellular convection over the Southeast Pacific, Atmos. Chem. Phys., 11, 2341-2370, doi:10.5194/acp-11-2341-2011, 2011a.

Wood, R., Mechoso, C. R., Bretherton, C. S., Weller, R. A., Huebert, B., Straneo, F., Albrecht, B. A., Coe, H., Allen, G., Vaughan, G., Daum, P., Fairall, C., Chand, D., Gallardo Klenner, L., Garreaud, R., Grados, C., Covert, D. S., Bates, T. S., Krejci, R., Russell, L. M., de Szoeke, S., Brewer, A., Yuter, S. E., Springston, S. R., Chaigneau, A., Toniazzo, T., Minnis, P., Palikonda, R., Abel, S. J., Brown, W. O. J., Williams, S., Fochesatto, J., Brioude, J., and Bower, K. N.: The VAMOS Ocean-Cloud-AtmosphereLand Study Regional Experiment (VOCALS-REx): goals, platforms, and field operations, Atmos. Chem. Phys., 11, 627-654, doi:10.5194/acp-11-627-2011, 2011 b.

Wood, R., Leon, D. C., Lebsock, M., Snider, J. R., and Clarke, A. D.: Precipitation driving of droplet concentration variability in marine low clouds, J. Geophys. Res., 117, D19210, doi:10.1029/2012JD018305, 2012.

Xue, H., Feingold, G., and Stevens, B.: Aerosol effects on clouds, precipitation, and the organization of shallow cumulus convection, J. Atmos. Sci., 65, 392-406, 2008.

Yang, M., Blomquist, B. W., and Huebert, B. J.: Constraining the concentration of the hydroxyl radical in a stratocumulus-topped marine boundary layer from sea-to-air eddy covariance flux measurements of dimethylsulfide, Atmos. Chem. Phys., 9, 92259236, doi:10.5194/acp-9-9225-2009, 2009.

Zuidema, P., Li, Z., Hill, R. J., Bariteau, L., Rilling, B., Fairall, C., Brewer, W. A., Albrecht, B., and Hare, J.: On trade wind cumulus cold pools, J. Atmos. Sci., 69, 258-280, doi:10.1175/JAS-D-110143.1, 2012a.

Zuidema, P., Leon, D., Pazmany, A., and Cadeddu, M.: Aircraft millimeter-wave passive sensing of cloud liquid water and water vapor during VOCALS-REx, Atmos. Chem. Phys., 12, 355-369, doi:10.5194/acp-12-355-2012, 2012b. 